\title{
Paleoceanographic Perturbations and the Marine Carbonate System during the Middle to Late Miocene Carbonate Crash-A Critical Review
}

\author{
Inga Preiss-Daimler ${ }^{1}$, Stergios D. Zarkogiannis ${ }^{2,3, * \mathbb{D}}$, George Kontakiotis ${ }^{3} \mathbb{D}$, Rüdiger Henrich ${ }^{1}$ and $^{-}$ \\ Assimina Antonarakou ${ }^{3}$ \\ 1 Faculty of Geosciences, University of Bremen, Klagenfurter Straße 4, D-28359 Bremen, Germany; \\ preissi@web.de (I.P.-D.); henrich@uni-bremen.de (R.H.) \\ 2 Department of Earth Sciences, University of Oxford, South Parks Road, Oxford OX1 3AN, UK \\ 3 Department of Geology \& Geoenvironment, National \& Kapodistrian University of Athens, \\ Panepistimiopolis Zografou, 15784 Athens, Greece; gkontak@geol.uoa.gr (G.K.); aantonar@geol.uoa.gr (A.A.) \\ * Correspondence: stergios.zarkogiannis@earth.ox.ac.uk
}

check for updates

Citation: Preiss-Daimler, I.; Zarkogiannis, S.D.; Kontakiotis, G.; Henrich, R.; Antonarakou, A. Paleoceanographic Perturbations and the Marine Carbonate System during the Middle to Late Miocene Carbonate Crash-A Critical Review. Geosciences 2021, 11, 94. https:// doi.org/10.3390/geosciences11020094

Academic Editor: Angelos G Maravelis; Jesus Martinez-Frias

Received: 14 January 2021

Accepted: 15 February 2021

Published: 17 February 2021

Publisher's Note: MDPI stays neutral with regard to jurisdictional claims in published maps and institutional affiliations.

Copyright: (c) 2021 by the authors. Licensee MDPI, Basel, Switzerland. This article is an open access article distributed under the terms and conditions of the Creative Commons Attribution (CC BY) license (https:// creativecommons.org/licenses/by/ $4.0 /)$.

\begin{abstract}
This study intends to review and assess the middle to late Miocene Carbonate Crash (CC) events in the low to mid latitudes of the Pacific, Indian, Caribbean and Atlantic Oceans as part of the global paleoceanographic reorganisations between 12 and $9 \mathrm{Ma}$ with an emphasis on record preservation and their relation to mass accumulation rates (MAR). In the Eastern Pacific the accumulation changes in carbonate and opal probably reflect an El-Niño-like state of low productivity, which marks the beginning of the CC-event (11.5 Ma), followed by decreased preservation and influx of corrosive bottom waters (10.3 to $10.1 \mathrm{Ma}$ ). At the same time in the Atlantic, carbonate preservation considerably increases, suggesting basin-to-basin fractionation. The low-latitude Indian Ocean, the Pacific and the Caribbean are all characterised by a similar timing of preservation increase starting at 9.6-9.4 Ma, while their MARs show drastic changes with different timing of events. The Atlantic preservation pattern shows an increase as early as $11.5 \mathrm{Ma}$ and becomes even better after 10.1 Ma. The shallow Indian Ocean (Mascarene plateau) is characterised by low carbonate accumulation throughout and increasing preservation after 9.4 Ma. At the same time, the preservation in the Atlantic, including the Caribbean, is increasing due to enhanced North Atlantic deep-water formation, leading to the increase in carbonate accumulation at $10 \mathrm{Ma}$. Moreover, the shoaling of the Central American Isthmus might have helped to enhance Caribbean preservation after 9.4 Ma. Lower nannoplankton productivity in the Atlantic should have additionally contributed to low mass accumulation rates during the late CC-interval. Overall, it can be inferred that these carbonate minima events during the Miocene may be the result of decreased surface ocean productivity and oceanographically driven increased seafloor dissolution.
\end{abstract}

Keywords: carbonate crash events; biogenic bloom; Neogene ocean circulation; carbonate dissolution; mass accumulation rates; Middle-Late Miocene paleoclimate

\section{Introduction}

The Miocene Carbonate Crash (CC) events include several sharp reductions in carbonate concentration and/or accumulation occurring in various marine systems around the world, such as the equatorial Pacific and Indian Ocean [1-4]; the Caribbean Sea [5]; the equatorial [6,7]; and South Atlantic [8-10]; or the Southern Ocean [11]) during the middle to late Miocene (13-9 Ma). Although global in character, the onset of this widespread phenomenon is diachronous, with the initial phases of carbonate reduction occurring at $\sim 13.2 \mathrm{Ma}$ at the equatorial Indian Ocean [3] and $\sim 11.5 \mathrm{Ma}$ at the Caribbean $[5,12]$ and the eastern Pacific [13]. Moreover, beyond timing, the duration and magnitude in terms of the number of the different decline events are not consistent, and possible causes are 
discussed controversially. Postulations of potential mechanisms include changes in deep water circulation, shoaling of the Calcite Compensation Depth (CCD), shifts in shallow to deep carbonate fractionation, terrigenous dilution, productivity, preservation changes, evolutionary trends, and adaptations of the main calcareous plankton groups $[1,3,4,14-16]$. During the middle to late Miocene major reorganisations on land and in the oceans induced prominent shifts in the global climate system, including important changes of plate tectonic settings (e.g., the closure of the Indonesian Seaway (IS) [17] and uplift of the Central American Seaway (CAS) [18-20]. The subsidence of the Greenland-Scotland Ridge is associated with secular variations in its bathymetry induced by variations in temperature and buoyancy of the Iceland mantle plume [21,22], opening and widening of the Frame Strait [23], as well as the uplift of high mountain ranges, in particular the Himalaya and Tibet Plateau as well as the Andes [24]. This, in turn, strongly influenced continental weathering [25] inducing the formation of new huge fluvial drainage systems like the Amazon [26] and therefore the increased major nutrient (e.g., phosphorous and silica) delivery to the oceans (e.g., [27-29]). During the Miocene strong variations in high-latitude climates are also observed. A gradual warming during the early to middle Miocene (24 Ma to $15 \mathrm{Ma}$ ) is followed by rapid cooling until the end of the Miocene [30-37]. Contemporaneously, the ice shield on Antarctica expanded considerably [38,39] and the first small-dimensioned ice sheets were initiated in the Northern Hemisphere [40-46], leading to the equivalent $\sim 40-60 \mathrm{~m}$ sea level drop [47]. Holbourn, et al. [48] and Tian, et al. [49] have also suggested that there was a linkage between the brief high production at 14 Ma to Atlantic cooling.

The asymmetric cooling resulted in more vigorous trade winds in the southern hemisphere and displacement of the Inter Tropical Convergence Zone (ITCZ) towards the north $[50,51]$. The global climate cooled stepwise as recorded in both benthic $[30,35,49,52]$ and planktonic $[49,53-55]$ foraminiferal $\delta^{18} \mathrm{O}$ values. The Miocene isotope events (Mievents) that denote increases in ice volume and / or surface and deep water cooling [52,56-58], which however are not always traceable among sites [59]. This was connected with major reorganisations of surface and deep water circulation, in particular, the initiation of modern low latitude upwelling systems in the Atlantic [8,10,60] and Pacific Oceans [61]. Wright, et al. [62] and Wright and Miller [21] place the initiation of North Component Water (NCW), a precursor to the modern North Atlantic Deep Water (NADW) and a primary component of deep-water convection, in the late early Miocene. More recently, Poore, et al. [22] stated that based on composite Atlantic, Pacific and Southern Ocean $\delta^{13} \mathrm{C}$ benthic foraminifera records there is no evidence of significant NCW overflow over the Greenland-Scotland Ridge before $12 \mathrm{Ma}$, which is consistent with evidence from Cd/Ca ratios [63].

The change in circulation mode further induced a shift in nutrient redistribution, which is manifested in the middle Miocene "silica switch" that marks the intensification of opaline deposition in the global oceans, associated with the evolutionary diversification of diatoms between 15 and $10 \mathrm{Ma}$ [64-68]. According to Lyle and Baldauf [13], the nutrients were more accessible during that time because of a combination of oceanographic and biochemical factors, including higher organic matter degradation in the upper water column and deep-intermediate nutrient pathways that efficiently recycled these components to the upwelling zones. This opal burst was also associated with the worldwide enhancement of carbonate, phosphate and barium accumulation rates, the vertical extension of the oxygen minimum zones $[8,69]$ and the body-size increase of many groups of large predatory marine vertebrates [70], such as fishes [71,72], marine mammals [73] and seabirds [74]. However, with the exception of species-specific (e.g., Orbulina universa [75]) and localized adaptations (e.g., $[37,76,77])$, the response of planktonic organisms in such oceanic environments is still poorly understood. Schmidt, et al. [78] found a shift in size of mid to low latitude foraminiferal assemblages through the Cenozoic with extreme development towards larger sizes in the late Miocene. Moreover, coccolithophores are suspected to react to oceanographic revolutions, showing extraordinary size trends during the late Miocene (e.g., Calcidicus leptoporus [79]; Reticulofenestra [80]). 
Variability in the size of marine plankton is directly relevant to calcium carbonate $\left(\mathrm{CaCO}_{3}\right)$ and carbon dioxide $\left(\mathrm{CO}_{2}\right)$ production. Carbonate accumulation patterns are crucial to understand circulation patterns and climate change, since they are reflecting a balance of productivity and preservation on the sea floor. Global carbonate budgets should display a steady state of riverine influx and burial rate of calcium carbonate [81]. Because of the similarity of eustatic sea level changes and fluctuations of the CCD over the path of the Cenozoic [82], changes in the CCD were associated with shelf-to-basin fractionation. The underlying assumption is that during high sea level, carbonate accumulation would preferably take place on shelves rather than the open ocean [83,84]. In order to trace CCD changes classical approaches, certain carbonate percentages or Carbonate Mass

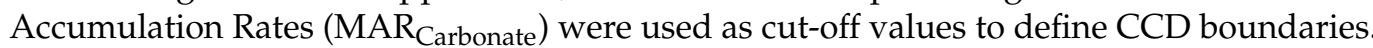
For instance, Roth, et al. [5] used the $0.1 \mathrm{~g} / \mathrm{cm}^{2} / \mathrm{ky}$ carbonate flux to reconstruct CCD changes in the deep Pacific throughout the middle to late Miocene CC-events, while Berger and Wefer [85] or Van Andel, et al. [86] used the $20 \mathrm{wt} . \%-\mathrm{CaCO}_{3}$ as the level of the CCD (see Figure 1A). A closer look at preservation proxies might reveal discrepancies between certain value CCD reconstructions and their relation to carbonate productivity levels or dissolution intensities. Therefore, in this study, we want to review the carbonate crash events from ODP cores of low to mid latitudes with emphasis on available carbonate preservation proxy data. The review is supplemented by original data contribution of material from ODP Site 1237 in the SE-Pacific in front of Peru (Supplementary Table S1).
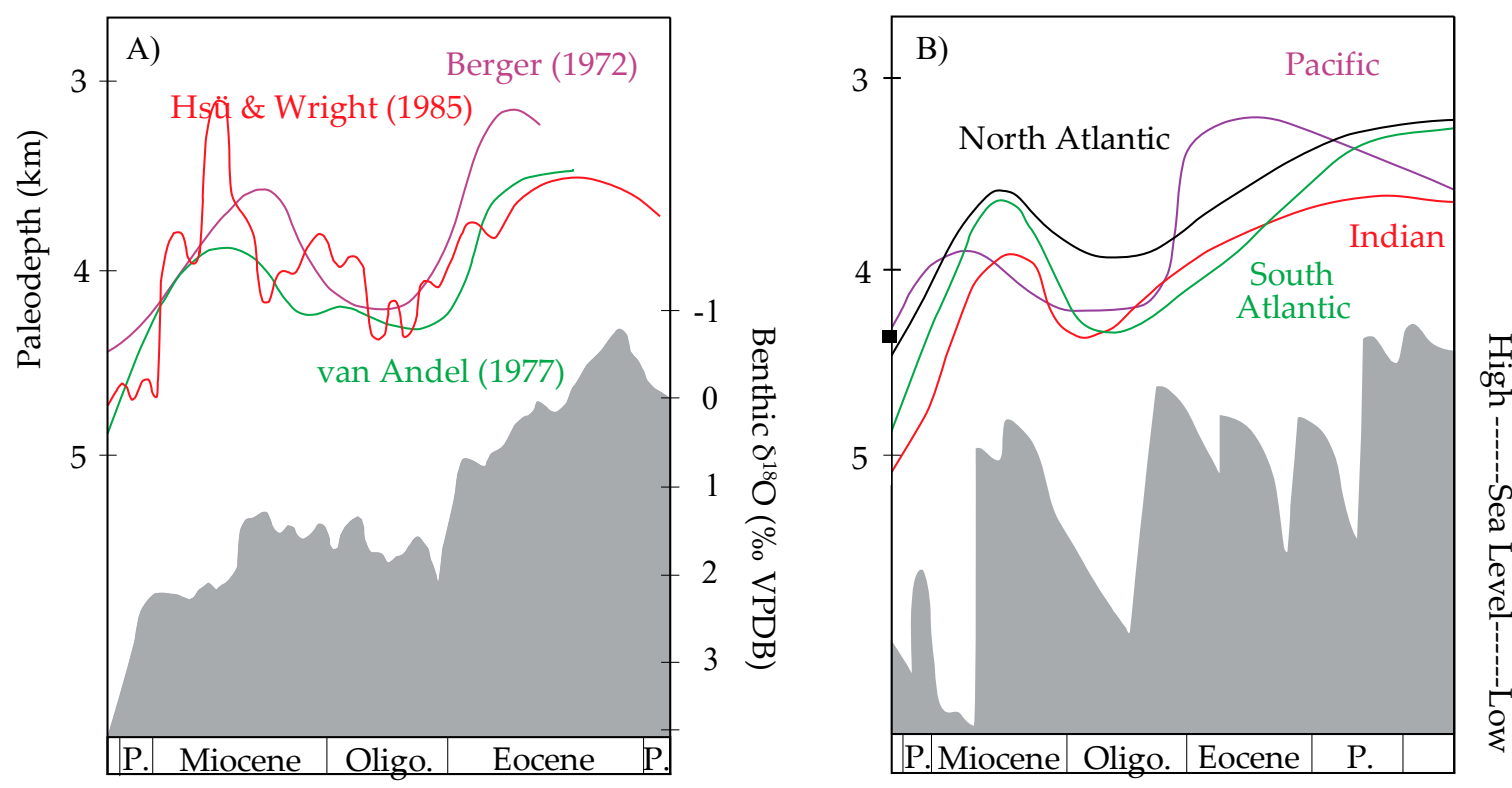

Figure 1. (A) Calcite Compensation Depth (CCD) reconstructions of the South Atlantic from Berger [83], Van Andel, et al. [86], and Hsü and Wright [87]. (B) Compiled CCD reconstructions for the mains oceans after Berger and Wefer [85].

\section{Strategies to Detect Carbonate Crash Mechanisms: Discrimination between Dilution, Productivity, and Dissolution}

Due to the technical advance of coring deep ocean floor sediments with hydraulic piston corers (e.g., during legs of the Ocean drilling program-ODP), there is the possibility to investigate a huge archive of well dated continuous sedimentary successions spanning the middle to late Miocene. A first look at a pelagic carbonate rich sedimentary sequence can give a hint to carbonate variations expressed as cyclic gradational variations in sediment colour, where darker colour bands represent carbonate decreases. This method is however inappropriate for sediments of very high carbonate contents, where even severe dissolution or productivity decreases are not reflected with apparent decreases in the carbonate contents (hence no changes in their colour bands). A strong dilution signal (e.g., through a change in the ratio of opal to carbonate sedimentation or terrigenous input) can also produce low 
carbonate contents. Besides the observation of carbonate contents, which can be lowered due to dilution, dissolution, decreased productivity or changing ratio of opal/calcite in the rain rate, mass accumulation rates (MAR) give a measure of the component burial per surface and time and are calculated as follows:

$\operatorname{MAR}_{\text {component }}\left[\mathrm{g} \mathrm{cm}^{-2} \mathrm{kyr}^{-1}\right]=$ proportion of the component $\times$ linear sedimentation rate $(\mathrm{cm} / \mathrm{ky}) \times \mathrm{dry}$ bulk

where in ODP records the Gamma ray attenuation porosity evaluator (GRAPE) data and discrete density measurements are often used to calculate dry bulk densities. Routinely MARs are reported every 1 My increment accounting for low resolution age models. Additionally, values from composite sections have to be corrected by a growth factor to account for core expansions and disturbances [88].

MARs can help to identify whether changes in downcore carbonate contents are due to dilution or productivity/dissolution changes. The quality of these data depends on the quality of the age model and the ablated sedimentation rates, with the highest resolution gained by orbitally tuned age models. Such models interpret the sediment composition as sedimentary response to orbital cycles and is based on high resolution data of density, colour and magnetic susceptibility or geochemical measurements in the framework of classical magneto- and biostratigraphy. However, sedimentation rates might be handled with care if there are special burial circumstances involved such as the rapid sedimentation of diatom mats, which are laminated sediments that can form thick and spatial widespread deposits [89-91]. These sediments are rather interpreted as results of complex surface water processes than deep water dissolution phases [92-94]. Additionally, re-depositional events such as turbidites and slumps or phases of no deposition (hiatus) disturb the premise of slow and steady pelagic sedimentation, supposed to form an even veneer on the ocean floor topography. The process of sediment focusing and lateral advection is also under discussion. Indicative attempts to correct for this are the correction of MAR by ${ }^{230} \mathrm{Th}$ normalisation $[95,96]$ or assuming a constant rain rate from extra-terrestrial ${ }^{3} \mathrm{He}[97,98]$.

However, MARs are the key data to observe CC-events. If decreasing accumulation rates of carbonate are accompanied by steady and low terrigenous accumulation, dilution can be excluded as a main factor. What remains then is the question of whether $\mathrm{MAR}_{\text {Carbonate }}$ minima are due to lowered productivity or dissolution. Depending on the paleo-water depth of the observation, one will make a first hypothesis based on the fact that at greater depth, calcite will be dissolved more easily, and at shallower depth, productivity will be the most important factor. Lowered carbonate supply tends to increase the possibility of dissolution and will be balanced by a rising CCD. However, especially under high productivity conditions, dissolution above the lysocline contributes significantly to overall dissolution [99]. Herein, the rain ratio of organic carbon to $\mathrm{CaCO}_{3}$ is an indicator for high productivity. Elevated proportions of organic carbon are often associated with high rates of opal accumulations [100]. The accumulation of opal in the form of diatom frustules might favour the preservation of carbonates. No evidence of enhanced dissolution of foraminifera has been observed within diatom mats [101], which might be attributed to the fast-settling velocities and/or the strong meshwork that suppresses benthic activity. The release of silica in pore waters might as well act against carbonate dissolution [102]. A higher proportion of benthic organisms can also point to higher productivity of surface waters, but might be also evidence of dissolution (e.g., $[69,103])$. In many cases, it is reasonable to take into account multiple proxies (e.g., sand content and/or the planktonic foraminiferal fragmentation index [104]) investigated on splits of the sand fraction. Foraminiferal fragmentation has shown to be a robust indicator of carbonate dissolution in deep sea sediments [105-107]. The examined Miocene tests of foraminifera appear opaque and recrystallized due to early diagenetic alterations; however, we expect that the diagenesis will not alter the whole test fragmentation index. The validity of these methods is restricted to dissolution above the CCD. Nannofossil based dissolution indices might help to find clues for dissolution 
intensities, despite the high potential of ecological control on abundance patterns. The application of these preservation proxies might be even better under strong dissolution conditions and for application to closely spaced inter-site comparison such as a depth transect [108]. The absence of foraminifera or a strongly reduced taphonomic assemblage in dissolved sediments often inhibits the investigation and/or interpretation of stable isotopes on benthic and planktonic faunas, which are standard proxies for circulation, productivity and climate, however here also the less well understood nannofossils might fill the gap in reflection of surface water processes in future research.

The investigations of $\mathrm{MAR}_{\text {Carbonate }}$ at depth transects is especially meaningful in CCD reconstructions because site to site differences reveal the loss of carbonate from one site to another and other processes influencing carbonate MAR besides dissolution. In case of the Walvis Ridge depth transect winnowing, reworking and down-slope re-suspension seem to alter wt. $\%$ of carbonate even towards producing reversed gradients in carbonate contents [109], with higher carbonate contents at the deeper sites in comparison to the shallower ones. Another such example for a depressed carbonate depth gradient is at the Ontong Java plateau [110].

For the following comparison we have chosen several cores from low to mid latitudes of the world's main ocean representing key locations of the CC-events (see Table 1 and Figure 2). The MAR were recalculated following the method described above. Carbonate and coarse fraction data from ODP Site 1237 in the SE-Pacific represent the only new data on the middle to late Miocene. Component analysis on these samples was applied to representative splits of the $>63 \mu \mathrm{m}$ fraction with at least 300 particles counted. The fragmentation index here is the ratio of whole tests (shells comprising at least half of a whole planktonic foraminifera test) divided by the sum of whole tests and fragments. The framework of comparison of different datasets and calculations of MAR Carbonate is given by the age model.

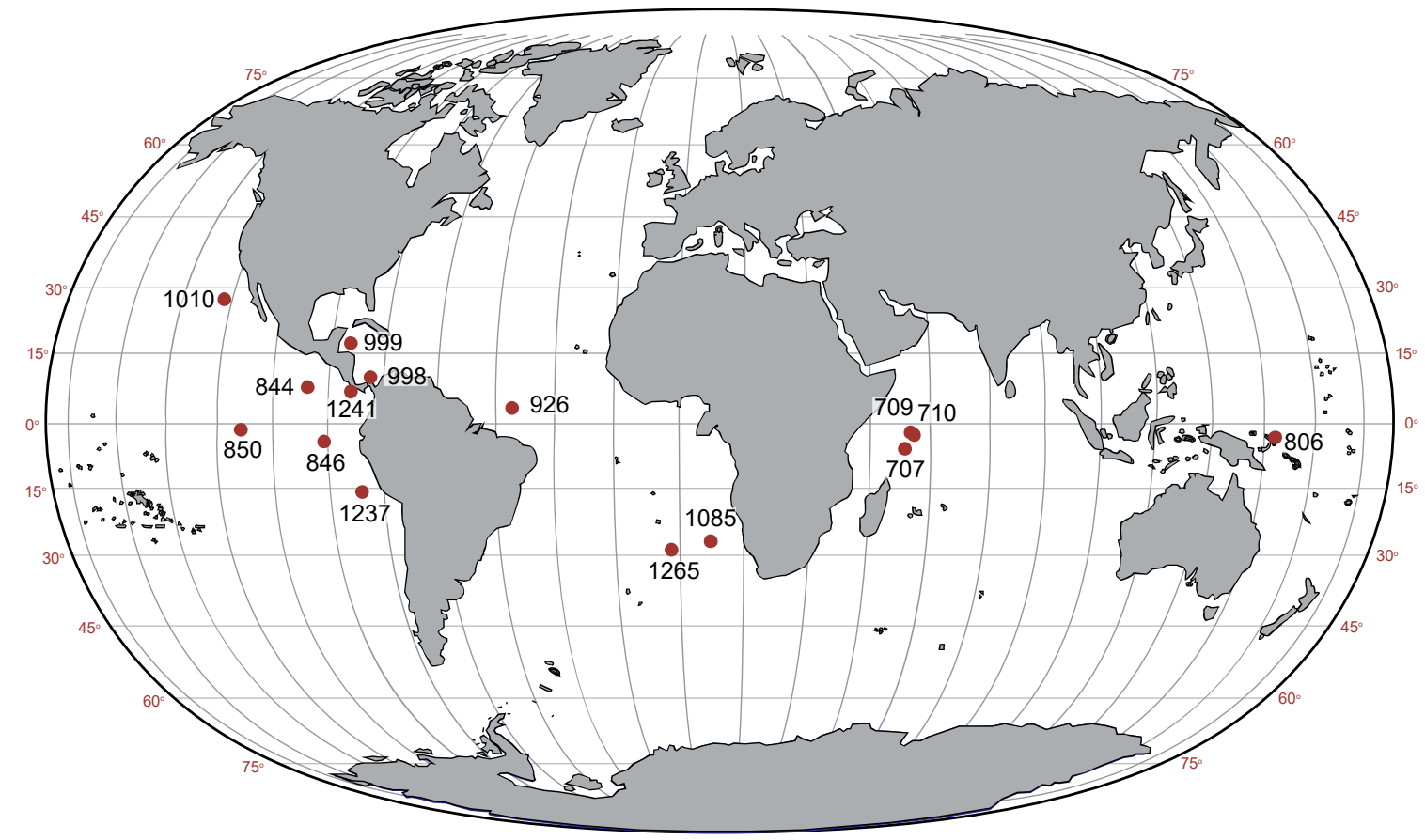

Figure 2. Locations of Ocean drilling program (ODP) sites reviewed in the present study for exhibiting Carbonate Crash events. New data from Site 1237 in the SE-Pacific. 
Table 1. Summary table of ODP legs and sites discussed in the present paper together with the bibliographic data sources for their chronostratigraphy, carbonate preservation and Mass Accumulation Rates. The symbols used to infer to the indexes are ^ Nannofossil Preservation, ${ }^{*}$ Foraminifer Preservation, ${ }^{\dagger}$ Coarse Fraction, ${ }^{\circ}$ MAR Carbonate, ${ }^{\S}$ MAR ${ }_{\text {Opal }}$.

\begin{tabular}{|c|c|c|c|c|c|c|}
\hline \multirow{2}{*}{ Region } & \multicolumn{2}{|c|}{ ODP Site } & \multirow{2}{*}{ Depth (m) } & \multirow{2}{*}{$\begin{array}{l}\text { Preservation Data } \\
\text { Sources }\end{array}$} & \multirow{2}{*}{ MAR Data Sources } & \multirow{2}{*}{$\begin{array}{c}\text { Age } \\
\text { Model/Biostratigraphy- } \\
\text { Source }\end{array}$} \\
\hline & Leg & Site & & & & \\
\hline \multicolumn{7}{|l|}{ East Pacific } \\
\hline Equatorial & \multirow{3}{*}{\multicolumn{2}{|c|}{$\begin{array}{l}844 \\
846 \\
850\end{array}$}} & 3415 & \multirow{2}{*}{$\begin{array}{l}\text { Farrell, et al. [4] } \\
+ \text { Vincent and } \\
\text { Toumarkine [118] }\end{array}$} & \multirow{2}{*}{ ○,§ Farrell, et al. [4] } & \multirow{2}{*}{$\begin{array}{l}\text { Shackleton and Hall [119]; } \\
\text { Raffi and Flores [120] }\end{array}$} \\
\hline Equatorial & & & 3296 & & & \\
\hline Equatorial & 1241 & & $\begin{array}{l}3786 \\
2027\end{array}$ & $\begin{array}{l}\text { Toumarkine [118] } \\
\text { * Mix, et al. [121] }\end{array}$ & ○, Mix, et al. [121] & Mix, et al. [121] \\
\hline Peru & \multicolumn{2}{|c|}{1237} & 3212 & $*,+$ This study & ${ }^{\circ}$ This study & Mix, et al. [121] \\
\hline California & \multicolumn{2}{|c|}{1010} & 3464 & * Lyle, et al. [122] & ${ }^{\circ}$ Lyle [123] & Fornaciari [116] \\
\hline West Pacific & 130 & 806 & 2521 & * Nathan and Leckie [115] & ${ }^{\circ}$ Berger [124] & Nathan and Leckie [115] \\
\hline \multicolumn{7}{|l|}{ Atlantic } \\
\hline Equatorial & 154 & 926 & 3598 & $\begin{array}{l}\text { * Preiss-Daimler, } \\
\text { et al. [125]; } \\
+ \text { Shackleton and } \\
\text { Crowhurst [126] }\end{array}$ & $\begin{array}{l}{ }^{\circ} \text { Preiss-Daimler, et al. } \\
\text { [125]; }{ }^{\circ} \text { King, et al. [6] }\end{array}$ & $\begin{array}{c}\text { Shackleton and } \\
\text { Crowhurst [126]; } \\
\text { Backman and Raffi [113] }\end{array}$ \\
\hline Benguela upwelling & 175 & 1085 & 1713 & \multirow{2}{*}{$\begin{array}{c}\text { Benthos/Plankton-ratio } \\
\text { Diester-Haass, et al. [8] } \\
*^{*}+\text { Kastanja and } \\
\text { Henrich [9] }\end{array}$} & ${ }^{\circ}$ Kastanja, et al. [60] & Westerhold, et al. [57] \\
\hline Walvis Ridge & 208 & 1265 & 3083 & & $\begin{array}{l}{ }^{\circ} \text { Kastanja and } \\
\text { Henrich [9] }\end{array}$ & Zachos, et al. [109] \\
\hline Caribbean & 165 & 999 & 2828 & $\begin{array}{c}{ }^{+} \text {Roth, et al. [5]; ^ Kameo } \\
\text { and Sato [127]; } \\
\text { ENd- Newkirk and } \\
\text { Martin [15] }\end{array}$ & ${ }^{\circ}$ Roth, et al. [5] & $\begin{array}{c}\text { Kameo and } \\
\text { Bralower [128] }\end{array}$ \\
\hline \multicolumn{7}{|l|}{ Indian Ocean } \\
\hline Mascarene Plateau & \multirow{3}{*}{115} & 707 & 1541 & & $\begin{array}{l}{ }^{\circ} \text { Backman and } \\
\text { Raffi [113] }\end{array}$ & Rio, et al. [129] ${ }^{1}$ \\
\hline Mascarene Plateau & & 709 & 3038 & $\begin{array}{l}{ }^{+} \text {Vincent and } \\
\text { Toumarkine [118] }\end{array}$ & $\begin{array}{l}{ }^{\circ} \text { Backman and } \\
\text { Raffi [113] }\end{array}$ & Rio, et al. [129] ${ }^{1}$ \\
\hline Mascarene Plateau & & 710 & 3812 & $\begin{array}{l}{ }^{+} \text {Vincent and } \\
\text { Toumarkine [118] }\end{array}$ & $\begin{array}{l}{ }^{\circ} \text { Backman and } \\
\text { Raffi [113] }\end{array}$ & Rio, et al. [129] ${ }^{1}$ \\
\hline
\end{tabular}

\footnotetext{
${ }^{1}$ Updated to Berggren, et al. [114].
}

\section{Age Control}

The comparison of the cores from the eastern Pacific (Leg 138, Leg 202), Atlantic (Leg 154, Leg 1085) and the Caribbean (Leg 165) is advantageous because they are based on the same biostratigraphy using bioevents dated by Flores, et al. [111] from Leg 138. Age control of Leg 138 records is provided by biostratigraphical studies over the whole record, astronomical tuning of GRAPE density down to $10 \mathrm{Ma}$ and magnetostratigraphical correlation in the interval younger than 13.25 Ma [112]. The astronomical tuning of Ceara Rise Site 926 based on correlation of magnetic susceptibility maxima to Northern Hemisphere insolation minima. The orbital solution of records was also compared to high resolution biostratigraphy from 5 to $14 \mathrm{Ma}$ [113]. Age models from Indian Ocean Leg 115 were updated to the common standard of Berggren, et al. [114] timescale. An updated age model was also used for Site 806 from the Ontong Java Plateau [115]. Age models of the eastern Pacific Site 1010 along Baja California [116] and Site 1241 in the Eastern Equatorial Pacific (EEP) did not provide magenetostratigraphic control, however displayed the low latitude standard zonation of calcareous nannofossil. At Site 1237 off Peru magnetostratigraphy could be applied giving excellent age control with all chrons and subchrons according to GPTS between 8.4 Ma and 12.4 Ma (Chron 4r and Chron 5Ar, [117]). This scale is in good accordance with calcareous nannofossil datums.

\section{The Carbonate Crash Events-Timing and Mechanisms}

In this section, compiled data of MARs as well as preservation proxies during the CC-interval and hypotheses about trigger mechanisms will be summarized for each oceanic basin. Existing theories concerning the CC-events in the deep (>3000 $\mathrm{m}$ water depth) EEP 
from Leg 138 will be complemented by regional examples in order to compose NE and SE Pacific records into an overview picture of the Eastern Pacific. Results from Leg 202 deliver insight into intermediate water processes in the EEP (Site 1241) and (original) results of a deep-water record off Peru (Site 1237) reflect processes in the SE Pacific. Additionally, sedimentary processes from the upwelling region along the California margin (Leg 167-Site 1010) provide valuable information about the paleoceanography in the NE Pacific. In particular, proxy data from the Caribbean (Sites 998 and 999) as a key area of the CCevents will be critically reviewed and reinterpreted. The Atlantic is represented by western equatorial Ceara Rise (Site 926) and Benguela upwelling (Site 1085) records. Sites of the depth transect of the Mascarene plateau $(707,709,710)$ stand here exemplarily for the low latitude Indian Ocean.

The stress in our reviewing observations lies on the available estimates of preservation of calcareous fossils along with MARs of the main biogenic components (opal and carbonate). The data and sources are listed in Table 1.

\subsection{The Pacific Carbonate Crash Events}

The modern equatorial Pacific surface productivity is characterised by an asymmetry between the east and the west [123]. The Western Pacific Warm water pool (WPWP) forms a stable water mass with a deep thermocline well recorded both in geochemical (isotope) and foraminiferal (assemblages) data [130,131]. In contrast to the moderate carbonate accumulation in the west, the eastern equatorial Pacific (EEP) accumulation of carbonates is mostly influenced by the upwelling intensity and an asymmetric lysocline, which is generally shallow in the east and deeper east of the East Pacific Ridge (EPR). Upwelling waters in the EEP are sourced from the Equatorial Undercurrent (EUC), which has its origin in the west Pacific and combines waters of both hemispheres (e.g., [132,133]). The eastern boundary currents (Humboldt and California current) form the prerequisite for coastal upwelling along the western boundaries of the two Americas. Oceanic productivity is furthermore distinctly influenced by the ENSO (El Niño -Southern Oscillation) phenomenon [134,135]. A strong El Niño event significantly reduces deep-water upwelling by deepening the thermocline, and finally leads to the breakdown of plankton productivity of upwelling regions in the eastern Pacific [14]. These modern patterns might have their roots in the Miocene influenced through gateway configurations [136]. The emergence of the Indonesian Seaway (IS) blocks the westward flow of warm waters to the Indian Ocean and allows warm waters to pile up to form the WPWP [115]. Generally, the strength of circulation is driven by the trade winds and boundary currents along the continents, and a slackening of these currents would tend to reduce the intensity of upwelling waters and result in a deeper thermocline in the eastern Pacific. Thus, the questions concerning the Miocene carbonate accumulation in the equatorial Pacific are: Can we find the oceanographic patterns compared to today's features and how relevant are these surface processes in comparison to deep water circulation changes?

\subsubsection{The Eastern Equatorial Pacific}

One of the first studies reporting unusually low carbonate contents during the Late Miocene (i.e., between 9.6 and 9.2 Ma) is by Vincent [137] on the section of DSDP Site 310 on the Hess Rise and in the northern central Pacific. ODP Leg 138 recovered excellent cores from the EEP. Changes in MAR Carbonate first followed a stepwise decline in various sites of the EEP from 11.2 to $9.5 \mathrm{Ma}$, with pronounced changes in the Guatemala basin (see Figure 3 Site 844) and Peru basin (Figure 3 Site 846) east of the EPR. This interval is also characterised by shifts in dominance of carbonate versus opal in sediments, indicating changing surface water ecology as well as deep circulation. At $9.5 \mathrm{Ma}, \mathrm{MAR}_{\text {Carbonate }}$ dropped to zero reaching the carbonate crash nadir. Evidence from nannofossil preservation [4] and MAR Carbonate point to a rapid rise of the local CCD of about $800 \mathrm{~m}$ to water depth of about 3400$3200 \mathrm{~m}$ at $10 \mathrm{Ma}$ [1]. After this brief dissolution event the carbonate accumulation did not recover but the preservation, as indicated by nannofossil and foraminifer indices, 
increase after 8.9 Ma [4]. West of the EPR in the Central Pacific basin, the MAR ${ }_{\text {Carbonate }}$ also shows minima centred at 9.5 Ma. Here changes are less clear with milder influence of dissolution as indicated by better nannofossil preservation and no obvious change to higher opal/carbonate ratios like in the Guatemala basin.

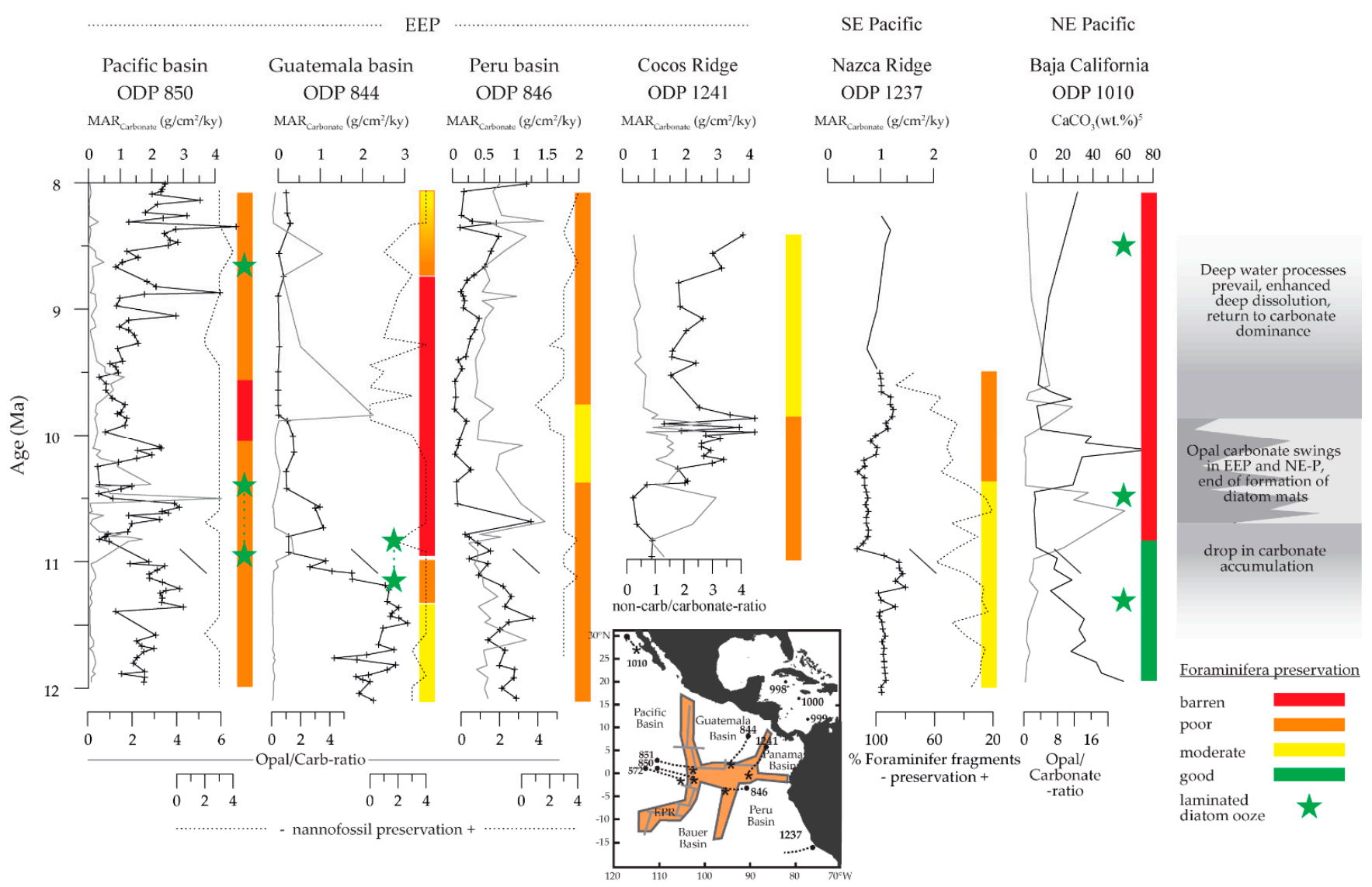

Figure 3. The phases of the Eastern Pacifc CC-events can be roughly divided into three phases. First a drop in carbonate accumulation at 11.5 to 10.8 Ma. Afterwards opal and carbonate accumulate in alternating phases ("swings") and the deep-water signal of dissolution sets in at about 10.3 to 10.Ma. For data reference see Table 1. Color bars refer to the preservation state of planktonic foraminifera as found in the ODP Initial Site Reports.

Another characteristic feature of the sediments is the occurrence of laminated diatom mat deposits in the near equator sites (sites 849-851) of the Central Pacific basin at the beginning and the end of the CC event (Figure 3 indicated by stars). These sediments must have probably formed as rapid fallouts of equatorial frontal zones developed during La Niña-like events $[89,115]$. The compact structure of diatom mats furthermore prohibited bioturbation and thus laminae appear well preserved [94,138]. However, the diatom abundance was reduced during the crash nadir and radiolaria dominated the opal instead.

Lyle, et al. [1] concluded that the restriction of carbonate saturated deep-water flows from the Atlantic to the Pacific through the emerging CAS would trigger the dissolution in the EEP. As an alternative scenario, deep water formation in the North Atlantic would result in basin-to-basin fractionation, and displacement of corrosive Southern Component Water (SCW) towards the Pacific in turn triggering enhanced dissolution in the deep EEP. However, the comparing of timing of these events could not lead to a consistent picture concerning NADW production [4].

\subsubsection{The West Equatorial Pacific (Site 806)}

The restriction of the flow of waters through the IS and the CAS is believed to have had a major impact on the circulation system including the distribution of temperature 
and nutrients in surface and near surface waters in the Pacific. The development of the WPWP, the Equatorial Counter-current system and alternating hydrographic features similar to modern El Niño and La Niña patterns are placed within the middle to late Miocene $[14,89,115,139,140]$. These models stress the productivity component in the highly dynamic equatorial system and represent an accomplishment to the models solely based on circulation-dissolution explanations. Li, et al. [140] place the establishment of the WPWP in the South China Sea at $10 \mathrm{Ma}$ as evidenced by increased abundance of mixed layer foraminifera and the decline of deeper living foraminifera (i.e., the extinction of Globoquadrina dehiscens). Similar results in the equatorial region place the initiation of the WPWP at 8 Ma [139].

Nathan and Leckie [115] found evidence for the development of a Proto-WPWP at 11.6 to 9.6 Ma based on foraminifer faunal analyses and stable isotope gradients of mixed layer and thermocline species at Site 806 (2520 m water depth) on the Ontong Java Plateau (see Figure 4). Thus, the establishment of a modern like circulation pattern influenced by the closure of the IS and the arising possibility of piling up warm waters in the west Pacific could have occurred that early. The authors mention that the equatorial undercurrent would have been strengthened by the evolution of a WPWP like today bringing nutrient enriched subsurface waters to the EEP. If the carbonate crash events in the EEP were related to the emergence of this circulation pattern one would find El Niño condition during a weak WPWP and better stratification in the west Pacific surface waters.

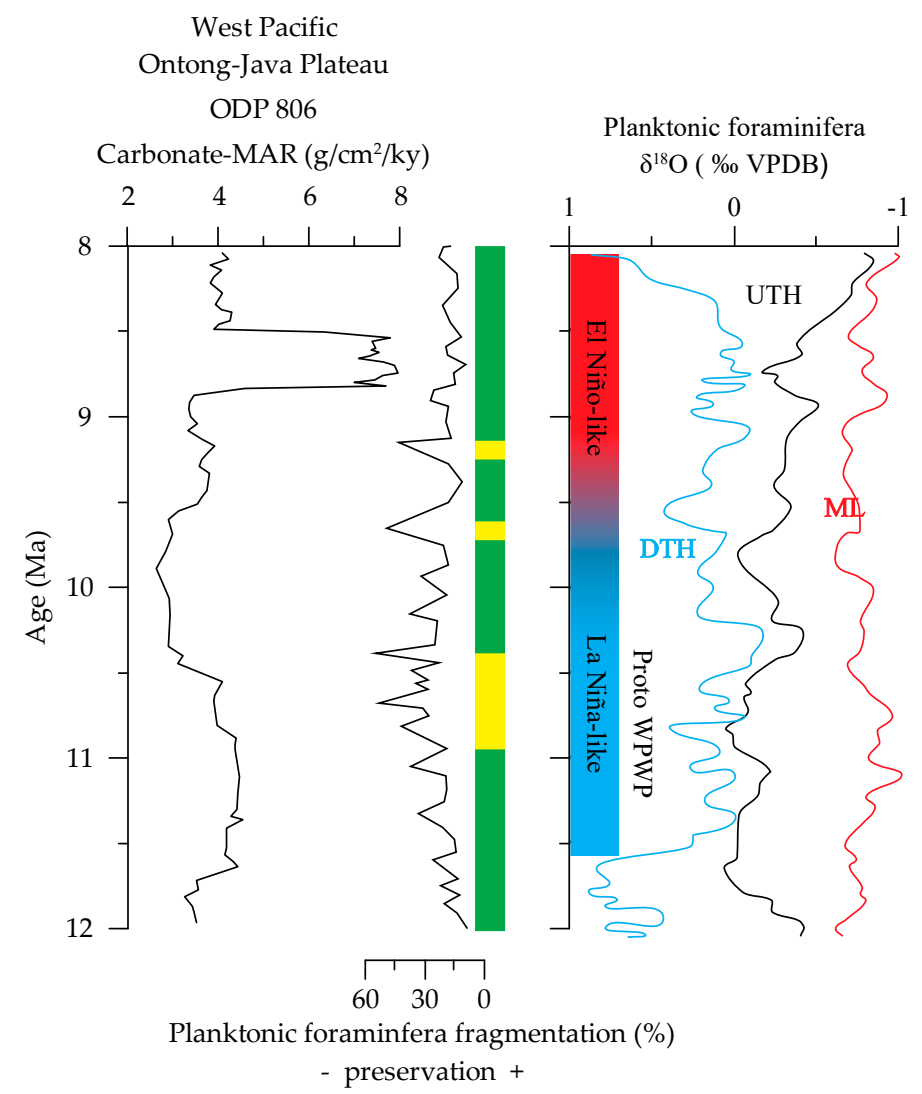

Figure 4. Data after Nathan and Leckie [115] showing the Ontong-Java plateau site 806. The oxygen stable isotope record of deep dwelling foraminifera (DTH), foraminifera record supposed to show the upper thermocline level (UTH) and a mixed layer record (ML). The convergence of DTH and UTH representatives is interpreted as the first occurrence of a stable WPWP. Colour bars refer to the preservation state of planktonic foraminifera as found in the ODP Initial Site Reports. The planktonic foraminifera preservation is preferably good, with lower values at about 10.5 to $9.5 \mathrm{Ma}$.

According to the above model, the dissolution of carbonates by corrosive deep waters during the carbonate crash event was delayed in the early phase (at about 11.5 Ma) through 
high productivity in a La Niña like phase in the EEP, which would explain the offset in CC-events between the Caribbean and Pacific. With regard to this hypothesis and a change from La Niña to El Niño conditions at about 10 to 9 Ma the question arises if these shifts are imprinted in the productivity along eastern boundary currents in other regions of the Eastern Pacific as found during modern El Niño events (e.g., [141,142]). In the following part, these questions will be addressed to cores from the California upwelling and from the SE Pacific.

\subsubsection{The California Upwelling (Site 1010)}

The California upwelling system was investigated during Leg 167. Sediments of Site 1010 (offshore) and 1021 (coastal upwelling) recorded a major drop in opal contents

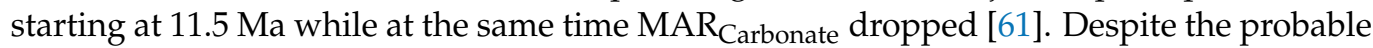
beginning of NADW circulation, which would have generally enhanced silica availability in the Pacific, certain intervals favoured offshore and others coastal sedimentation of opal. The coastal to offshore opal fractionation was enhanced through low temperature gradients among latitudes damping the strength of the California current accompanied by a deep nutricline [64]. According to this mechanism, the time interval from 12-11.5 Ma can be interpreted in terms of increased strength in current intensity favouring offshore opal sedimentation, while a slackening of the currents occurred from 11.5 to $10 \mathrm{Ma}$ inducing coastal fractionation. This kind of record is associated with a general decreasing trend in opal concentration reaching its minimum at $10 \mathrm{Ma}$ at both sites (shown for Site 1010, see Figure 3). Interestingly, here laminated diatom rich sediments appear as well in similar intervals in comparison to the EEP (see Figure 3). The preservation of planktonic foraminifera is poor except of an interval below $148 \mathrm{mbsf}$ (approximately 11.5 Ma), where they appear well preserved within diatom rich sediments and species composition indicates an upwelling sequence [122]. The enhanced preservation of foraminifera is probably a result of rapid burial through particle loading. These results strengthen the hypothesis of a general decreasing productivity trend, as it can be associated with an El Niño phase, influencing both opal and MAR Carbonate $_{\text {at Site }} 1010$ at the same time when carbonate accumulation dropped in the EEP.

\subsubsection{The Intermediate EEP (Site 1241) and the South East Pacific (Site 1237)}

Leg 202 offers two sites to test hypotheses concerning the influence of deep and surface water processes during the CC-events in the EP. Site 1241 is positioned at $2040 \mathrm{~m}$ water depth above the lysocline on the Coccos Ridge in the EEP and displays the shallowest sedimentary record in comparison to the deep sites of Leg 138 (all deeper than $3000 \mathrm{~m}$ water depth). The calcareous microfossil tests show evidence of strong dissolution during the oldest part of recovered sediments (11-10 Ma), when opal and TOC concentrations were relatively high as well as $\mathrm{MAR}_{\text {Carbonate }}$ (Figure 3). After $10 \mathrm{Ma}$, tests of foraminifera and nannofossil show moderate preservation associated with increasing carbonate content but a drop in $\mathrm{MAR}_{\text {Carbonate }}$ as the site moves away from the high productivity equatorial belt. The strong dissolution event ends here at the time when the rapid drop in MAR Carbonate occurs in the Guatemala and Peru basin. Here the preservation of foraminifera is not supported by the sedimentation of diatom rich layers like in Site 1010. In this shallower site, there might have been a higher probability of organic matter arriving at the sea floor and building a benthic fluff layer in which dissolution of foraminifera fossils might have be accelerated in comparison to deeper sites [143]. In the deeper sites of the EP, therefore, the presence of diatoms might simply enhance the preservation probability by rapid settling of aggregates and particle clusters, which also in their extreme form of diatom mats hinder bioturbation and support rapid burial as positive factors in preservation of calcareous shells. Thus, dissolution at Site 1241 was likely the result of organic matter degradation; however,

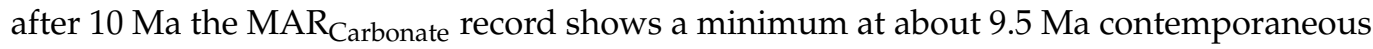
with the nadir of EEP CC-events, suggesting a general low in carbonate productivity followed by an increase afterwards. 
Site 1237 (Naszca Ridge, 3212 m water depth) is bathed by Antarctic-CircumpolarDeep water and was mostly moving latitudinally during the last $10 \mathrm{Ma}$, coming closer to the modern high productivity belt of the Peru/Chile upwelling [121]. The MAR ${ }_{\text {Carbonate }}$ record experienced a first drop at about $11 \mathrm{Ma}$ and stayed low until it recovers between 10.2 and $9.8 \mathrm{Ma}$, followed by a second slight decrease. The preservation of planktonic foraminifera was preferably good until $10.3 \mathrm{Ma}$, after which the decreasing trend in the number of whole foraminifera tests and the enrichment of the coarse fraction with noncalcareous components (e.g., sponge spicules, radiolarians, ash) point to intensification of dissolution. According to findings at Site 1237, the decreasing $\mathrm{MAR}_{\text {Carbonate }}$ might be assigned to generally lowered productivity until 10.3 Ma because during this period decreasing $\mathrm{MAR}_{\text {Carbonate }}$ are not clearly accompanied by decreased carbonate preservation. These findings support the hypothesis of a productivity decrease in the early phase of the Miocene CC-events and point to the intensification of deep-water corrosiveness increasing at about 10.3 to $10 \mathrm{Ma}$.

\subsubsection{The Caribbean Sea}

The Caribbean basin is characterised by influx of incoming carbonate corrosive waters as a mixture of mainly AAIW and upper NADW (e.g., [19,144]). The loop current is an important part in the global thermohaline circulation as surface waters gain salinity through evaporation [145], which is believed to have enhanced deep water formation in the North Atlantic (e.g., [146]).

Roth, et al. [5] modified the alternative model of Lyle, et al. [1] calling the influx of corrosive SCW responsible for dissolution in the equatorial Pacific. The tectonic situation in the Caribbean (emergence of the CAS and opening of intrabasinal seaways like the Pedro Channel) could have allowed for a strengthening of the Caribbean Current and establishment of the loop current. Based upon the observation of different coccolith assemblages present on either side of the CAS during an interval from 10.7 to $9.4 \mathrm{Ma}$, the Pacific-Atlantic connection might have been weakened [127]. At the same time the establishment of surface water connection among sites 999 and 998 and the possible initiation of the loop current was postulated based on similar assemblages.

According to Roth, et al. [5], the changing circulation at the middle to late Miocene transition is well recorded in the contrasting carbonate preservation pattern observed in the Caribbean basin, the EEP, and the western equatorial Atlantic. In analogy to the theory of glacial interglacial preservation cycles [147] Roth, et al. [5] suggested that North Atlantic Intermediate Water (NAIW) flowed over shallow to intermediate depth sills on the Atlantic side of the Caribbean Basin during times of enhanced carbonate preservation (i.e., comparably to the glacial circulation of the Quaternary), while corrosive southern sourced intermediate water (ancient equivalent to AAIW) overflowed the sills during intervals of carbonate dissolution (i.e., comparably to interglacial circulation in the Quaternary). This would furthermore induce that during times of enhanced NCW formation the preservation becomes worse in the Caribbean (corrosive intermediate SCW), the EEP (displacement of SCW towards this region) and better in the deep Atlantic (NCW replacing SCW). This configuration was based on the correlation between carbonate MAR minima (Figure 5), periods of more intense Northern Component Water (NCW) production [21], and associated with a closed deep water exchange between the Atlantic and the Pacific Oceans.

The study of Newkirk and Martin [15] that compared carbonate mass accumulation rate patterns with evidence from $\mathrm{Nd}$ isotopes from fossil fish teeth and debris at Sites 998 and 999 in the Caribbean and Sites 846 and 1241 in the eastern equatorial Pacific support the assumption that waters sourced from the Pacific dominated the flow into the Caribbean during the Miocene Caribbean CC-events. A gradual decrease in carbonate MAR $\mathrm{C}_{\text {Carbonate }}$ and an associated increase in $\varepsilon \mathrm{Nd}$ values at Site 999 prior to the Caribbean crash (Figure 5) provide evidence for the introduction of a more corrosive Pacific intermediate water mass into the Caribbean as the CAS shoaled to critical depths for west to east flow. During the Caribbean carbonate crash (12-9 Ma), highly variable $\varepsilon N d$ values and MAR $\mathrm{Carbonate}$ 
record pulses of corrosive Pacific waters that filled the deep Caribbean basin. These pulses of Pacific through-flow correlate well with NCW production, suggesting that NCW production could occur with an open CAS and that flow system in the Caribbean region is linked to the global circulation patterns. After the Caribbean carbonate crash, $\varepsilon N d$ values gradually shifted to less radiogenic values, indicating a reduction in the amount of Pacific water flowing into the Caribbean coincident with the shoaling of the Isthmus of Panama.

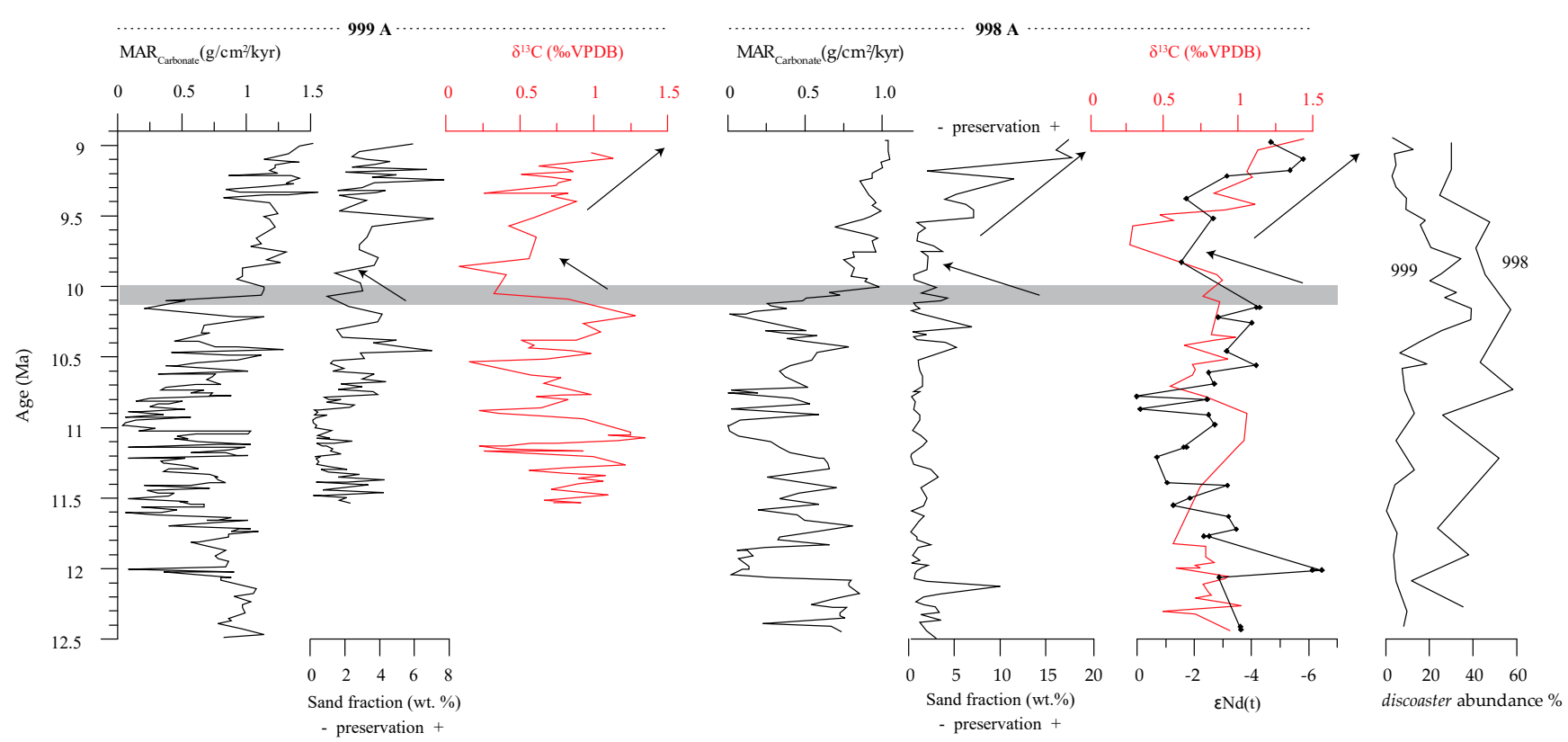

Figure 5. Caribbean records show that the preservation is increasing after 9.5 Ma. However, this development is in conflict with already enhanced MAR.

The comparison of preservation records (sand fraction) with carbonate accumulation of sites 999 and 998 suggests that the carbonate preservation is persistently worse, while the MAR $_{\text {Carbonate }}$ already recovered at $10 \mathrm{Ma}$. The sand fraction contents of Site 999 and 998 remain relatively low until 9.4 Ma. This trend is in accordance with lower values of benthic delta ${ }^{13} \mathrm{C}$ at both sites and $\mathrm{Nd}$ isotope trends from Site 998 indicating phases of dominance of corrosive waters from probably Pacific origin and a trend to better preservation afterwards. The absence of a particular abrupt excursion in the carbon isotopic curve towards lighter values does not implicate any global rise in greenhouse gas concentrations, such as methane release [148], which was proposed to explain reductions in seafloor carbonate by dissolution in the geologic past [149]. Another interesting pattern is the high abundance of discoaster nannoliths during the carbonate crash at sites 998 and 999 [127]. Although their abundance has originally been interpreted as an ecological signal, their apparent enrichment within the sediment may well be due to dissolution of other material [108], and may thus serve as another preservation proxy indicating that the CC-ended at 9.4 Ma. This would have the consequence that the establishment of the loop current cannot be inferred from assemblages. The meaning of such high abundances as an ecologic signal might point alternatively to an interval of low plankton productivity [111,150].

The complete closure of the Isthmus might not necessarily be a precondition to enhance carbonate preservation in the deep Caribbean basin. The comparison of the carbonate mass accumulation and preservation patterns of the Caribbean sites [125] and those of the western equatorial Atlantic (i.e., Ceara Rise; Figure 4) reveals that the anti-correlation postulated by Roth, et al. [5] for these two contrasting regions is not evident from the records (see Figure 5). Instead, the records of Site 999 and 926 seem to be in phase, however much worse carbonate preservation was prevailing at Site 999 compared to the deeper Site 926, indicating the presence of more corrosive bottom waters. The similar phase trends 
in the preservation records might suggest that the NADW formation did not trigger a return flow and influx of corrosive waters but seem to weaken/replace/dilute the flux of corrosive waters into the Caribbean. Modelling results showed that NCW formation is possible with an open CAS [151]. However, NCW\% estimates and preservation records from the Caribbean and Ceara Rise differ in this important interval as discussed in the next section. Simulation for a restricted exchange through the CAS predicts a drastic shoaling of the lysocline in the EEP [152]. However, at about the time of final closure (3 Ma) of the CAS, the carbonate compensation depth was deepening in the EEP rather than shoaling [153] according to the sedimentary data.

\subsection{The Atlantic Ocean}

The middle to late Miocene Atlantic is characterised by the fade of opal [64] and the onset of significant deep water formation in the North as well as initiated upwelling off Southwest Africa [154]. Krammer, et al. [10] and Kastanja, et al. [60], studying the Miocene records of ODP Sites 1085 and 1087 on the continental margin off Namibia, found severe reductions in carbonate contents and carbonate accumulation rates. These were attributed rather to the reduction of coccolith productivity than to dissolution. Kastanja, et al. [60] showed that a first major drop in $\mathrm{CaCO} 3$ concentration between 10.4 and 10.1 Ma was related mainly to changes in calcareous nannoplankton production, while another drop between 9.6 and $9 \mathrm{Ma}$ is thought to have been triggered by a combination of plankton export production changes and dilution; the latter, presumably occurring in response to high shelf supply in this region during global lowering of sea level $[8,60]$ (Figure 6). The carbonate dissolution is further supported by the increasing benthic/plankton $(\mathrm{B} / \mathrm{P})$ foraminiferal ratios, since planktic foraminiferal tests are generally thin-walled and more susceptible to dissolution than robust thick-walled benthic foraminifers $[155,156]$. That increase observed at Site 1085 from about 9.4 Ma is attributed to enhanced dissolution due to supply from the shelf [8] and possibly aridification with first major dust supply at 9.6 Ma [157].

Miocene South Atlantic sediments on the Walvis Ridge display short-term dissolution events that were closely related to variations in NCW circulation in the deep circulation loop of the South Atlantic, as shown in Kastanja and Henrich [9]. They registered overall good to moderate preservation in the Miocene sections evidencing persistent NCW supply to this southern location. However, some decreases of preservation at 11.6 and 10.4 Ma were found to coincide with Miocene glacial events (Mi-events), suggesting an increase of SCW influence during these intervals, which occurred as a response to the intensification of Antarctic ice sheet development. At $10.4 \mathrm{Ma}$, a change to overall better preservation points to a weakening of SCW that occurred as a response to the strengthening of NCW.

The western equatorial Atlantic (Ceara Rise, ODP Leg 154) sedimentation patterns are as well influenced by increasing preservation and distinct lows in high frequent carbonate accumulation occurring at 11.8 to $11 \mathrm{Ma}$ and 10.4 to $10.1 \mathrm{Ma}$ at Site $926[6,125]$ accompanied by low sand fraction contents [126]. The comparison with Caribbean Site 999 shows similarity in MAR $\mathrm{R}_{\text {Carbonate }}$ and sand fraction, suggesting dissolution and/or productivity pattern in phase [125]. The general trend in preservation based on interpretation of sand fraction contents shows increasing preservation from $11.5 \mathrm{Ma}$ and onwards. The preservation minima are associated with Mi events 5 and 6 suggesting a causal relation to influx of corrosive SCW acting as the dominant deep water source during pulsed cooling. The relation to NCW\% estimates by Wright and Miller [21] and Poore, et al. [22] shows that the preservation record is roughly in phase until $10.1 \mathrm{Ma}$, when the increasing preservation is not reflected in increasing NCW\%. The interpretation of carbon isotopes are the basis of NCW\% estimates through mixing calculations [158]. The estimates might be confused by the overall low productivity during this time interval (EP, [2,EP, 121]), which might prevent formation of reliable benthic $\delta^{13} \mathrm{C}$ gradients among ocean basins. Furthermore, a recent modelling study suggests that the carbon isotope pattern in the Atlantic is not related to 
the variations in sill depth of the Greenland Scotland ridge, questioning a major tectonic influence on circulation patterns [159].

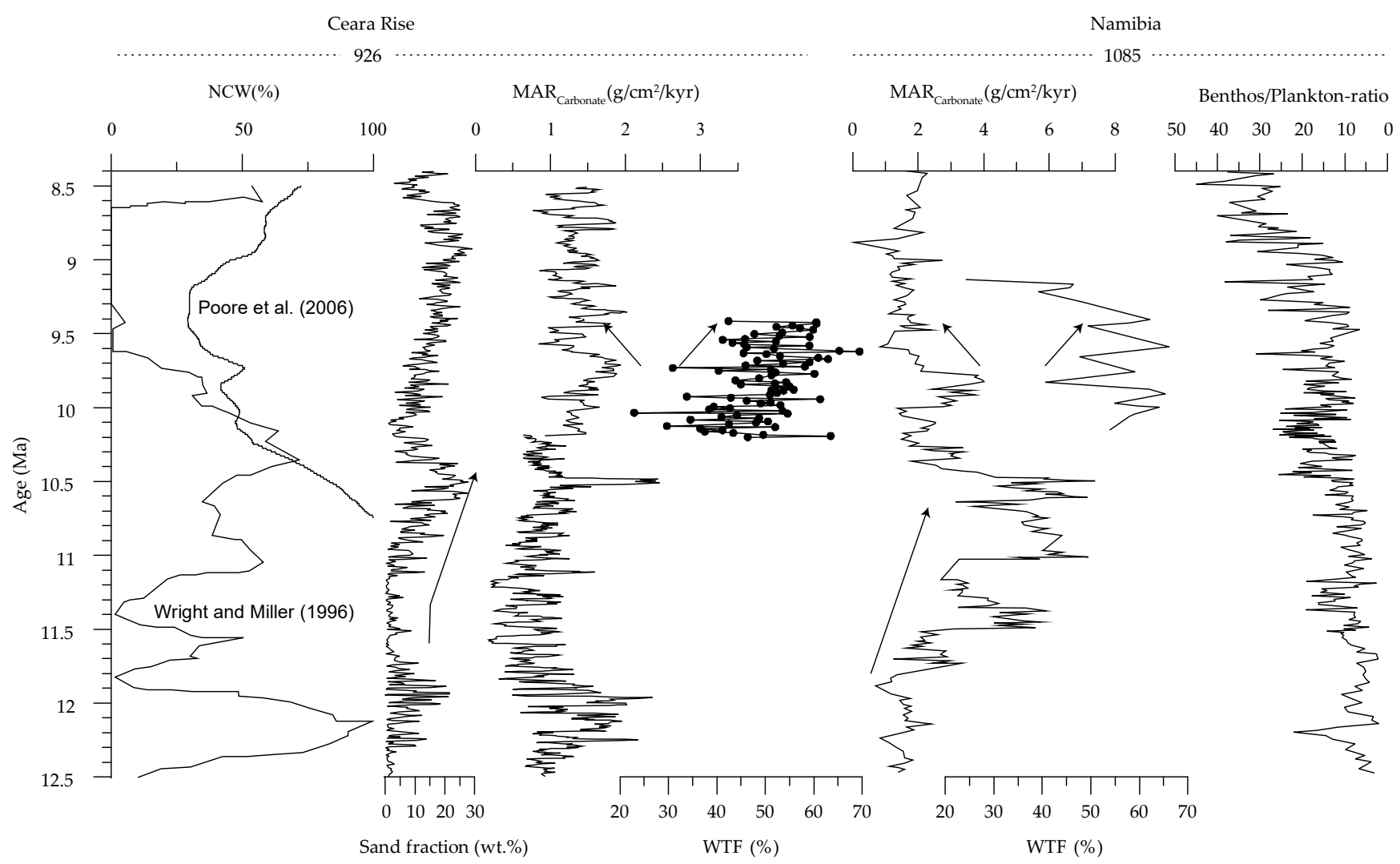

Figure 6. The Atlantic exhibits in general a preservation pattern in accordance with Northern Component Water (NCW) formation, but the decreasing NCW\% estimate (centred at about $9.25 \mathrm{Ma}$ ) is not accompanied by decreasing but by increasing preservation in the deep Atlantic as shown by the sand and whole foraminifera tests (WTF) contents. Site 1085 preservation is decreasing at about 9.5 Ma showing a different preservation pattern to the deep Atlantic, but possibly both sites suffered from productivity decreases of calcareous nannoplankton (in this phase preservation increases and MAR decreased [125].

\subsection{The Indian Ocean}

The modern Indian Ocean can be divided into a northern high productivity region (Arabian Sea and the pelagic ocean north of $10^{\circ} \mathrm{N}$ ), which is influenced by the monsoonal gyre system and the lower productive region of the subtropical gyre to the south. The Indian Ocean was drilled through early ODP Legs 115, 117, 121 and 122, and recovered cores mostly shallower $2500 \mathrm{~m}$ water depth with the exception of Leg 115, which offers a depth transect. Peterson, et al. [2] noted that despite the completely different regional settings the carbonate sedimentation and gradients among sites were low during most of the Miocene followed by a marked step in the late Miocene accompanied by reappearing opal components in the sediment (Figure 7).

The initiation or intensification of the monsoon in connection to the uplift of the Himalaya and Tibetian Plateau as a major cause of pronounced oceanic productivity has been rejected (e.g., [160]) as well as the hypothesis of Tethyan outflow water dominating at intermediate depth during the middle to late Miocene [161,162]. The overall similarity suggests a global pattern assigned to sea level fluctuations and shelf-basin fractionation rather than a regional influence like the monsoon [2]. The increase in both carbonate and opal accumulation was named biogenic bloom and reported as well in the Pacific and Atlantic within a broad time interval between $\sim 10$ and 3.8 Ma $[4,8,13,163]$. In the Indian Ocean it was accompanied by reappearing opal components and benthic foraminifera indicative of high productivity $[160,162,164]$ in the sediment as indicator for high productivity. How- 
ever, the shift in depth gradients in the Late Miocene implies changes in circulation as well [2]. Unfortunately, winnowing gives a strong imprint in shallow sediments (Site 707) causing foraminiferal sand contributions of about $50 \%$ (Figure 7). In comparison to Site 707 , the deeper Site $710(3812 \mathrm{~m})$ shows about the same MAR ${ }_{\text {Carbonate }}$ in accordance with aforementioned overall reduced gradients along the depth transect from 12 to 9.4 Ma right above the $\mathrm{LO}$ datum of $D$. hamatus.

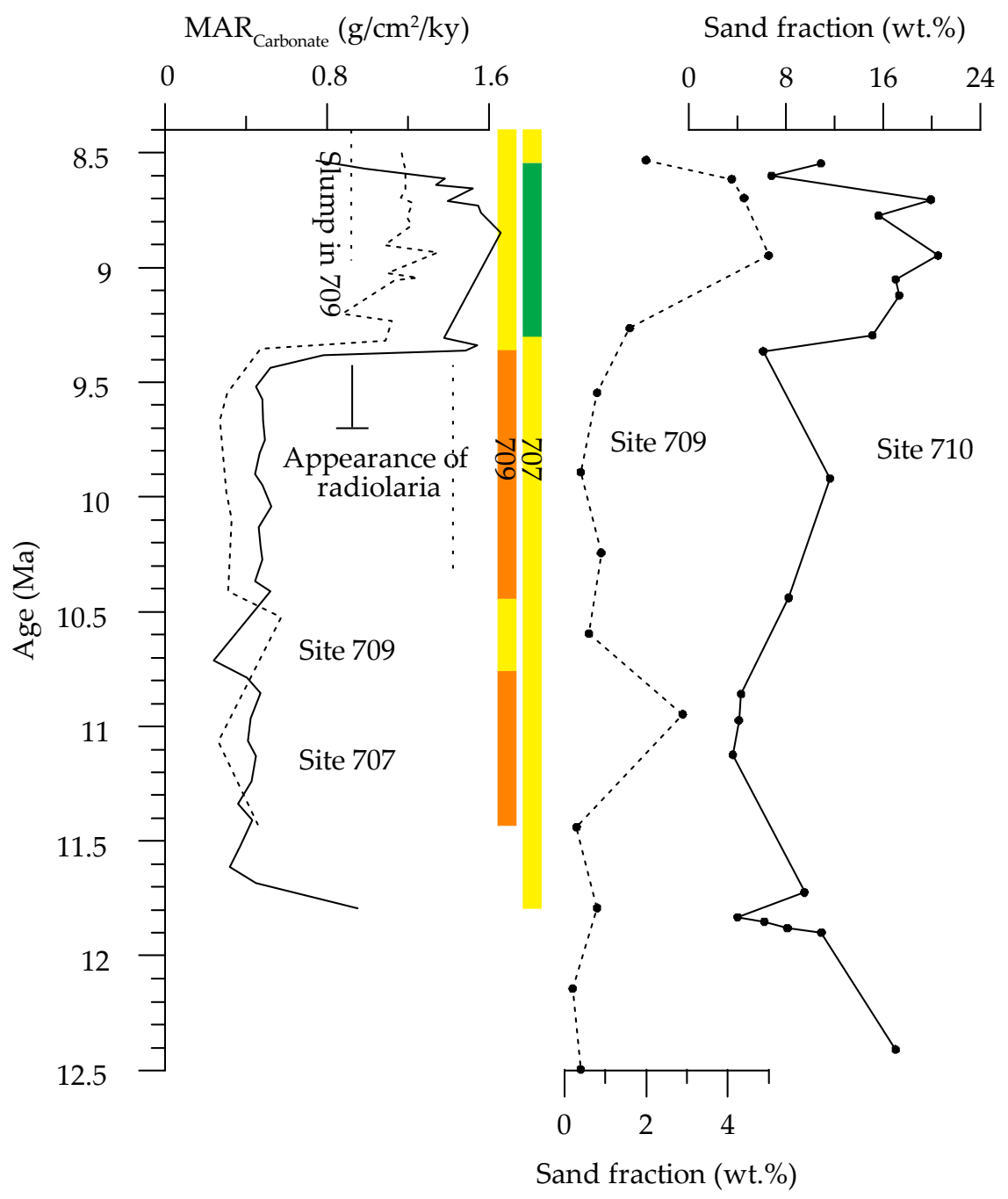

Figure 7. The Indian Ocean, represented by the Mascarene Plateau ODP sites 707, 709 and 710. The carbonate crash interval is characterized by very low carbonate MAR and low MAR gradients among different depths. The opal reappears in form of radiolaria at about $10 \mathrm{Ma}$. Coarse fraction contents point to better preservation after about 9.4 Ma. Colour bars refer to the preservation state of planktonic foraminifera as found in the ODP Initial Site Reports.

The age model of Site 710 is based on magnetostratigraphical correlations and resulted in a much earlier placement of the FO datum of D. hamatus than usual. However, the reduced depth gradient might be because of redepositional events in the deeper records but is not purely an artefact of the age model differences and evident among the other sites as described by Peterson, et al. [2]. In the deep sites, the comparison of sand fraction contents leads to interesting results: At Site 710 and 709, the record of coarse fraction suggests a change to better preservation at $9.5 \mathrm{Ma}$ as well as the abundance and preservation data on planktonic foraminifera [165]. The winnowed coarse fraction record of 707 is not shown but despite high coarse fraction contents the preservation of foraminifera here is changing 
from moderate to good. The reappearance of opal in form of radiolaria date to 9.7 at Site 707 and to $10.3 \mathrm{Ma}$ at site 709 .

The proportion of the sand fraction might be controlled by other processes besides dissolution. A size change in foraminifera became evident from $10 \mathrm{Ma}$ on [78]. This trend in low latitudes could have had an effect in the records shown. Winnowing could enhance the coarse fraction or dilution by finer grain sizes (nannofossils, terrigenous fraction) could decrease the coarse fraction. However, the investigation of multiple proxies or the observation of increasing sand fraction along with better preservation and higher abundance of planktonic foraminifera might confirm the interpretation as dissolution index.

\section{Conclusions}

The middle to late Miocene carbonate crash events mark a period of major perturbations in the marine carbonate system, which obviously were associated with several steps in reorganization of global deep and intermediate water circulation, affecting various parts of the global ocean basins differently in time and space. Since Miocene atmospheric $\mathrm{pCO}_{2}$ concentrations are known to be close to preindustrial levels [166] and with no particular excursions during the time of the CC events [167], the observed reductions in seafloor carbonates may mostly be the result of decreased productivity and reorganization of the corrosive deep-water masses rather than dissolution by other exogenic causes.

A review and comparison of the eastern equatorial records seem to strengthen the hypothesis of alternating El Niño/La Niña-like states, that influenced both opal and carbonate accumulation in the EEP on the California margin and off Peru. The emergence of IS probably allowed for the development of a temporary Western Pacific Warm water pool during a La Niña-like state associated with the sedimentation of diatom mats. The alternating productivity in opaline and calcareous plankton were the main cause rather than dissolution at least in the early phase of the carbonate crash events. The deepwater corrosiveness in the Pacific was pronounced at 10.5 to $9.4 \mathrm{Ma}$ and losing influence afterwards. The shallow water record of Site 1241 in the EEP showed severe supralysoclinal dissolution through phases of high productivity.

Phases of reduced calcareous nannoplankton productivity were evident both in the Atlantic (Benguela upwelling site 1085) and Pacific and were probably related to reorganizations of the upper water column and surface circulation changes. In the deep Atlantic the preservation change can be recognized at 10.5 to $10.1 \mathrm{Ma}$ already. Thus $10.5 \mathrm{Ma}$ might be the starting point of prolonged basin to basin fractionation through the onset of the deep convection in the North Atlantic.

Sand fraction contents and preservation of planktonic foraminifera from the deeper Caribbean and the Indian Ocean and Pacific show an increase at 9.3 to $9.5 \mathrm{Ma}$, which we interpret as the first widespread signal of better preservation indicating a lysocline turning point possibly related to CCD deepening (Figure 8). The Caribbean CC-events ends at the same time based on reinterpreted coarse fraction contents, $\delta^{13} \mathrm{C}$ signal and $\mathrm{Nd}$ isotope evidence as well as nannofossil indicators independent from the step to higher carbonate accumulation at $10 \mathrm{Ma}$, which was as well recognized at Ceara Rise. The similarity of coarse fraction and mass accumulation records of Ceara Rise and Caribbean, with however worse preservation in the Caribbean, leads to the conclusion that the influence of corrosive Pacific sourced waters in the Caribbean was dampened by NCW formation and not enhanced as previously assumed. The shoaling of the CAS might have contributed at 9.4 Ma to the Atlantic type preservation pattern in the Caribbean. 


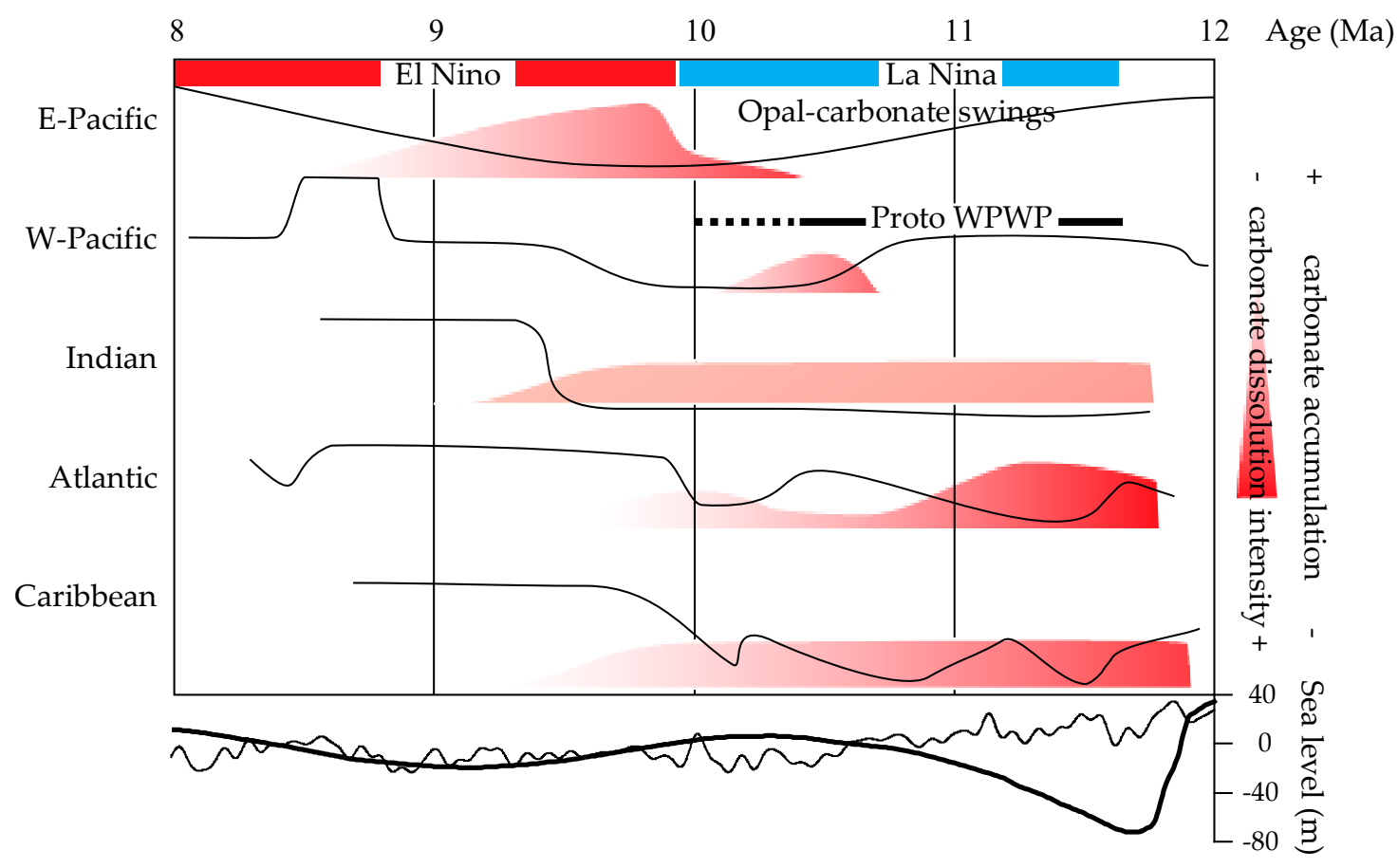

Figure 8. With the CC, the pattern of deep preservation changed in all ocean basins. The CCD rises in the EP and deepened probably first in the deep Atlantic, afterwards in the Caribbean and Indian Ocean. There is no clue to sea level, as a first order control on CC events.

While the mass of carbonate in all studies is constituted by coccoliths and other nannoliths, the use of the better-known foraminifera dominates the scientific output. However, changes in the fine fraction stable isotopes in the Atlantic, Caribbean and Pacific show drastic decreases from 11.5 to $10.5 \mathrm{Ma}[119,168,169]$, but are still hardly understood and interpretations are contrasting. Understanding these patterns and the further development of high-resolution age models would help to gain better insight into the CC-events regarding considerations on the timing and carbonate budgets.

Supplementary Materials: The following are available online at https:/ / www.mdpi.com/2076-326 3/11/2/94/s1, Table S1: Generated carbonate mass accumulation and foraminifera fragmentation index data for core ODP 1237.

Author Contributions: Conceptualization, I.P.-D.; writing—original draft preparation, I.P.-D.; writingreview and editing, S.D.Z. and G.K.; supervision, R.H. and A.A. All authors have read and agreed to the published version of the manuscript.

Funding: This study was funded by the Deutsche Forschungsgemeinschaft (DFG-Grant number He $1671 / 15)$.

Data Availability Statement: Generated carbonate mass accumulation and foraminifera fragmentation index data for core ODP 1237 are given as supplementary material.

Acknowledgments: We gratefully acknowledge the work of Helga Heilmann and Britt Kockisch providing the basic laboratory equipment and support. This research used samples provided by the Ocean Drilling Program (ODP). ODP is sponsored by the U.S. National Science Foundation (NSF) and participating countries under management of Joint Oceanographic Institutions (JOI).

Conflicts of Interest: The authors declare no conflict of interest. 


\section{References}

1. Lyle, M.; Dadey, K.A.; Farrell, J.W. The late Miocene (11-8 Ma) eastern Pacific carbonate crash; evidence for reorganization of deep-water circulation by the closure of the Panama Gateway. Proc. Ocean Drill. Program 1995, 138, 821. [CrossRef]

2. Peterson, L.C.; Murray, D.W.; Ehrmann, W.U.; Hempel, P. Cenozoic carbonate accumulation and compensation depth changes in the Indian Ocean. Synth. Results Sci. Drill. Indian Ocean 1992, 70, 311. [CrossRef]

3. Lübbers, J.; Kuhnt, W.; Holbourn, A.E.; Bolton, C.T.; Gray, E.; Usui, Y.; Kochhann, K.G.D.; Beil, S.; Andersen, N. The Middle to Late Miocene "Carbonate Crash" in the Equatorial Indian Ocean. Paleoceanogr. Paleoclimatol. 2019, 34, 813-832. [CrossRef]

4. Farrell, J.W.; Raffi, I.; Janecek, T.R.; Murray, D.W.; Levitan, M.; Dadey, K.A.; Emeis, K.-C.; Lyle, M.; Flores, J.-A.; Hovan, S. Late Neogene sedimentation patterns in the eastern Equatorial Pacific Ocean. Proc. Ocean Drill. Program 1995, 138, 717. [CrossRef]

5. Roth, J.M.; Droxler, A.W.; Kameo, K. The Caribbean carbonate crash at the middle to late Miocene transition; linkage to the establishment of the modern global ocean conveyor. Proc. Ocean Drill. Program 2000, 165, 249. [CrossRef]

6. King, T.A.; Ellis, W.G., Jr.; Murray, D.W.; Shackleton, N.J.; Harris, S.E. Miocene evolution of carbonate sedimentation at the Ceara Rise; a multivariate data/proxy approach. Proc. Ocean Drill. Program 1997, 154, 349. [CrossRef]

7. Murray, D.W.; Peterson, L.C. Biogenic carbonate production and preservation changes between 5 and 10 Ma from the Ceara Rise, western Equatorial Atlantic. Proc. Ocean Drill. Program 1997, 154, 375. [CrossRef]

8. Diester-Haass, L.; Meyers, P.A.; Bickert, T. Carbonate crash and biogenic bloom in the late Miocene: Evidence from ODP Sites 1085, 1086, and 1087 in the Cape Basin, southeast Atlantic Ocean. Paleoceanography 2004, 19. [CrossRef]

9. Kastanja, M.M.; Henrich, R. Grain-size variations in pelagic carbonate oozes from the Walvis Ridge-SE Atlantic Ocean (ODP Site 1265): A low resolution Miocene record of carbonate sedimentation and preservation. Mar. Geol. 2007, 237, 97-108. [CrossRef]

10. Krammer, R.; Baumann, K.-H.; Henrich, R. Middle to late Miocene fluctuations in the incipient Benguela Upwelling System revealed by calcareous nannofossil assemblages (ODP Site 1085A). Palaeogeogr. Palaeoclimatol. Palaeoecol. 2006, 230, 319-334. [CrossRef]

11. Diester-Haass, L.; Nees, S. Late Neogene History of Paleoproductivity and Ice Rafting South of Tasmania. In The Cenozoic Southern Ocean: Tectonics, Sedimentation, and Climate Change Between Australia and Antarctica; Exon, N.F., Kennett, J.P., Malone, M.J., Eds.; American Geophysical Union: Washington, DC, USA, 2013. [CrossRef]

12. Shackford, J.K.; Lyle, M.W.; Wilkens, R.; Tian, J. Data report; Raw and normalized elemental data along the Site U1335, Ui336, and U1337 splices from X-ray fluorescence scanning. Proc. Ocean Drill. Program 2014, 320, 17. [CrossRef]

13. Lyle, M.; Baldauf, J. Biogenic sediment regimes in the Neogene equatorial Pacific, IODP Site U1338: Burial, production, and diatom community. Palaeogeogr. Palaeoclimatol. Palaeoecol. 2015, 433, 106-128. [CrossRef]

14. Jiang, S.; Wise, S.W., Jr.; Wang, Y. Cause of the middle/late Miocene carbonate crash; dissolution or low productivity? Proc. Ocean Drill. Program 2007, 206, 24. [CrossRef]

15. Newkirk, D.R.; Martin, E.E. Circulation through the Central American Seaway during the Miocene carbonate crash. Geology 2009, 37, 87-90. [CrossRef]

16. Pälike, H.; Lyle, M.W.; Nishi, H.; Raffi, I.; Ridgwell, A.; Gamage, K.; Klaus, A.; Acton, G.; Anderson, L.; Backman, J.; et al. A Cenozoic record of the equatorial Pacific carbonate compensation depth. Nature 2012, 488, 609. [CrossRef]

17. Lee, T.-Y.; Lawver, L.A. Cenozoic plate reconstruction of Southeast Asia. Tectonophysics 1995, 251, 85-138. [CrossRef]

18. Collins, L.S.; Coates, A.G.; Berggren, W.A.; Aubry, M.-P.; Zhang, J. The late Miocene Panama isthmian strait. Geology 1996, 24, 687-690. [CrossRef]

19. Haug, G.H.; Tiedemann, R. Effect of the formation of the Isthmus of Panama on Atlantic Ocean thermohaline circulation. Nature 1998, 393, 673-676. [CrossRef]

20. Marshall, L.G. Land Mammals and the Great American Interchange. Am. Sci. 1988, 76, 380-388.

21. Wright, J.D.; Miller, K.G. Control of North Atlantic Deep Water Circulation by the Greenland-Scotland Ridge. Paleoceanography 1996, 11, 157-170. [CrossRef]

22. Poore, H.R.; Samworth, R.; White, N.J.; Jones, S.M.; McCave, I.N. Neogene overflow of Northern Component Water at the Greenland-Scotland Ridge. Geochem. Geophys. Geosyst. 2006, 7. [CrossRef]

23. Thiede, J.; Myhre, A.M. The paleoceanographic history of the North Atlantic-Arctic gateways; synthesis of the Leg 151 drilling results. Proc. Ocean Drill. Program 1996, 151, 645. [CrossRef]

24. Benjamin, M.T.; Johnson, N.M.; Naeser, C.W. Recent rapid uplift in the Bolivian Andes: Evidence from fission-track dating. Geology 1987, 15, 680-683. [CrossRef]

25. Filippelli, G.M.; Delaney, M.L. The oceanic phosphorus cycle and continental weathering during the Neogene. Paleoceanography 1994, 9, 643-652. [CrossRef]

26. Hoorn, C.; Guerrero, J.; Sarmiento, G.A.; Lorente, M.A. Andean tectonics as a cause for changing drainage patterns in Miocene northern South America. Geology 1995, 23, 237-240. [CrossRef]

27. Hermoyian, C.S.; Owen, R.M. Late Miocene-early Pliocene biogenic bloom: Evidence from low-productivity regions of the Indian and Atlantic Oceans. Paleoceanography 2001, 16, 95-100. [CrossRef]

28. Diester-Haass, L.; Billups, K.; Emeis, K.C. In search of the late Miocene-early Pliocene "biogenic bloom" in the Atlantic Ocean (Ocean Drilling Program Sites 982, 925, and 1088). Paleoceanography 2005, 20. [CrossRef]

29. Filippelli, G.M. The Global Phosphorus Cycle: Past, Present, and Future. Elements 2008, 4, 89-95. [CrossRef] 
30. Shevenell, A.E.; Kennett, J.P.; Lea, D.W. Middle Miocene ice sheet dynamics, deep-sea temperatures, and carbon cycling: A Southern Ocean perspective. Geochem. Geophys. Geosyst. 2008, 9. [CrossRef]

31. Tian, J.; Shevenell, A.; Wang, P.; Zhao, Q.; Li, Q.; Cheng, X. Reorganization of Pacific Deep Waters linked to middle Miocene Antarctic cryosphere expansion: A perspective from the South China Sea. Palaeogeogr. Palaeoclimatol. Palaeoecol. 2009, 284, 375-382. [CrossRef]

32. Tzanova, A.; Herbert, T.D.; Peterson, L. Cooling Mediterranean Sea surface temperatures during the Late Miocene provide a climate context for evolutionary transitions in Africa and Eurasia. Earth Planet. Sci. Lett. 2015, 419, 71-80. [CrossRef]

33. Herbert, T.D.; Lawrence, K.T.; Tzanova, A.; Peterson, L.C.; Caballero-Gill, R.; Kelly, C.S. Late Miocene global cooling and the rise of modern ecosystems. Nat. Geosci. 2016, 9, 843. [CrossRef]

34. Holbourn, A.E.; Kuhnt, W.; Clemens, S.C.; Kochhann, K.G.D.; Jöhnck, J.; Lübbers, J.; Andersen, N. Late Miocene climate cooling and intensification of southeast Asian winter monsoon. Nat. Commun. 2018, 9, 1584. [CrossRef]

35. Holbourn, A.; Kuhnt, W.; Frank, M.; Haley, B.A. Changes in Pacific Ocean circulation following the Miocene onset of permanent Antarctic ice cover. Earth Planet. Sci. Lett. 2013, 365, 38-50. [CrossRef]

36. Kontakiotis, G.; Besiou, E.; Antonarakou, A.; Zarkogiannis, S.D.; Kostis, A.; Mortyn, P.G.; Moissette, P.; Cornée, J.J.; Schulbert, C.; Drinia, H.; et al. Decoding sea surface and paleoclimate conditions in the eastern Mediterranean over the Tortonian-Messinian Transition. Palaeogeogr. Palaeoclimatol. Palaeoecol. 2019, 534, 109312. [CrossRef]

37. Vasiliev, I.; Karakitsios, V.; Bouloubassi, I.; Agiadi, K.; Kontakiotis, G.; Antonarakou, A.; Triantaphyllou, M.; Gogou, A.; Kafousia, N.; de Rafélis, M.; et al. Large Sea Surface Temperature, Salinity, and Productivity-Preservation Changes Preceding the Onset of the Messinian Salinity Crisis in the Eastern Mediterranean Sea. Paleoceanogr. Paleoclimatol. 2019. [CrossRef]

38. Warnke, D.A.; Allen, C.P.; Muller, D.W.; Hodell, D.A.; Brunner, C.A. Miocene-Pliocene Antarctic glacial evolution; a synthesis of ice-rafted debris, stable isotope, and planktonic foraminiferal indicators, ODP Leg 114. Antarct. Paleoenviron. Perspect. Glob. Chang. Part One 1992, 56, 311. [CrossRef]

39. Flower, B.P.; Kennett, J.P. The middle Miocene climatic transition: East Antarctic ice sheet development, deep ocean circulation and global carbon cycling. Palaeogeogr. Palaeoclimatol. Palaeoecol. 1994, 108, 537-555. [CrossRef]

40. Larsen, H.C.; Saunders, A.D.; Clift, P.D.; Beget, J.; Wei, W.; Spezzaferri, S. Seven Million Years of Glaciation in Greenland. Science 1994, 264, 952-955. [CrossRef]

41. Fronval, T.; Jansen, E. Late Neogene paleoclimates and paleoceanography in the Iceland-Norwegian Sea; evidence from the Iceland and Voring plateaus. Proc. Ocean Drill. Program 1996, 151, 455. [CrossRef]

42. Thiede, J.; Winkler, A.; Wolf-Welling, T.; Eldholm, O.; Myhre, A.M.; Baumann, K.-H.; Henrich, R.; Stein, R. Late Cenozoic History of the polar North Atlantic: Results from Ocean Drilling. Quat. Sci. Rev. 1998, 17, 185-208. [CrossRef]

43. Tian, J.; Yang, M.; Lyle, M.W.; Wilkens, R.; Shackford, J.K. Obliquity and long eccentricity pacing of the Middle Miocene climate transition. Geochem. Geophys. Geosyst. 2013, 14, 1740-1755. [CrossRef]

44. Moran, K.; Backman, J.; Brinkhuis, H.; Clemens, S.C.; Cronin, T.; Dickens, G.R.; Eynaud, F.; Gattacceca, J.; Jakobsson, M.; Jordan, R.W.; et al. The Cenozoic palaeoenvironment of the Arctic Ocean. Nature 2006, 441, 601-605. [CrossRef] [PubMed]

45. Darby, D.A. Arctic perennial ice cover over the last 14 million years. Paleoceanography 2008, 23. [CrossRef]

46. Krylov, A.A.; Andreeva, I.A.; Vogt, C.; Backman, J.; Krupskaya, V.V.; Grikurov, G.E.; Moran, K.; Shoji, H. A shift in heavy and clay mineral provenance indicates a middle Miocene onset of a perennial sea ice cover in the Arctic Ocean. Paleoceanography 2008, 23 [CrossRef]

47. John, C.d.M.; Karner, G.D.; Mutti, M. $\delta^{18} \mathrm{O}$ and Marion Plateau backstripping: Combining two approaches to constrain late middle Miocene eustatic amplitude. Geology 2004, 32, 829-832. [CrossRef]

48. Holbourn, A.; Kuhnt, W.; Lyle, M.; Schneider, L.; Romero, O.; Andersen, N. Middle Miocene climate cooling linked to intensification of eastern equatorial Pacific upwelling. Geology 2014, 42, 19-22. [CrossRef]

49. Tian, J.; Ma, W.; Lyle, M.W.; Shackford, J.K. Synchronous mid-Miocene upper and deep oceanic $\delta^{13} \mathrm{C}$ changes in the east equatorial Pacific linked to ocean cooling and ice sheet expansion. Earth Planet. Sci. Lett. 2014, 406, 72-80. [CrossRef]

50. Hovan, S.A. Late Cenozoic atmospheric circulation intensity and climatic history recorded by eolian deposition in the eastern Equatorial Pacific Ocean, Leg 138. Proc. Ocean Drill. Program 1995, 138, 615. [CrossRef]

51. Rea, D.K. The paleoclimatic record provided by eolian deposition in the deep sea: The geologic history of wind. Rev. Geophys. 1994, 32, 159-195. [CrossRef]

52. Zachos, J.; Pagani, M.; Sloan, L.; Thomas, E.; Billups, K. Trends, Rhythms, and Aberrations in Global Climate 65 Ma to Present. Science 2001, 292, 686-693. [CrossRef] [PubMed]

53. Mourik, A.A.; Abels, H.A.; Hilgen, F.J.; Di Stefano, A.; Zachariasse, W.J. Improved astronomical age constraints for the middle Miocene climate transition based on high-resolution stable isotope records from the central Mediterranean Maltese Islands. Paleoceanography 2011, 26. [CrossRef]

54. Rousselle, G.; Beltran, C.; Sicre, M.-A.; Raffi, I.; De Rafélis, M. Changes in sea-surface conditions in the Equatorial Pacific during the middle Miocene-Pliocene as inferred from coccolith geochemistry. Earth Planet. Sci. Lett. 2013, 361, 412-421. [CrossRef]

55. Shevenell, A.E.; Kennett, J.P.; Lea, D.W. Middle Miocene Southern Ocean Cooling and Antarctic Cryosphere Expansion. Science 2004, 305, 1766-1770. [CrossRef]

56. Miller, K.G.; Fairbanks, R.G.; Mountain, G.S. Tertiary oxygen isotope synthesis, sea level history, and continental margin erosion. Paleoceanography 1987, 2, 1-19. [CrossRef] 
57. Westerhold, T.; Bickert, T.; Röhl, U. Middle to late Miocene oxygen isotope stratigraphy of ODP site 1085 (SE Atlantic): New constrains on Miocene climate variability and sea-level fluctuations. Palaeogeogr. Palaeoclimatol. Palaeoecol. 2005, 217, 205-222. [CrossRef]

58. Miller, K.G.; Mountain, G.S.; Browning, J.V.; Kominz, M.; Sugarman, P.J.; Christie-Blick, N.; Katz, M.E.; Wright, J.D. Cenozoic global sea level, sequences, and the New Jersey Transect: Results From coastal plain and continental slope drilling. Rev. Geophys. 1998, 36, 569-601. [CrossRef]

59. Andersson, C.; Jansen, E. A Miocene (8-12 Ma) intermediate water benthic stable isotope record from the northeastern Atlantic, ODP Site 982. Paleoceanography 2003, 18. [CrossRef]

60. Kastanja, M.M.; Diekmann, B.; Henrich, R. Controls on carbonate and terrigenous deposition in the incipient Benguela upwelling system during the middle to the late Miocene (ODP Sites 1085 and 1087). Palaeogeogr. Palaeoclimatol. Palaeoecol. 2006, 241, 515-530. [CrossRef]

61. Lyle, M.; Koizumi, I.; Delaney, M.L.; Barron, J.A. Sedimentary record of the California Current system, middle Miocene to Holocene; a synthesis of Leg 167 results. Proc. Ocean Drill. Program 2000, 167, 341. [CrossRef]

62. Wright, J.D.; Miller, K.G.; Fairbanks, R.G. Early and Middle Miocene stable isotopes: Implications for Deepwater circulation and climate. Paleoceanography 1992, 7, 357-389. [CrossRef]

63. Delaney, M.L. Miocene benthic foraminiferal Cd/Ca records: South Atlantic and western equatorial Pacific. Paleoceanography 1990, 5, 743-760. [CrossRef]

64. Cortese, G.; Gersonde, R.; Hillenbrand, C.-D.; Kuhn, G. Opal sedimentation shifts in the World Ocean over the last 15 Myr. Earth Planet. Sci. Lett. 2004, 224, 509-527. [CrossRef]

65. Keller, G.; Barron, J.A. Paleoceanographic implications of Miocene deep-sea hiatuses. GSA Bull. 1983, 94, 590-613. [CrossRef]

66. Lazarus, D.; Barron, J.; Renaudie, J.; Diver, P.; Türke, A. Cenozoic Planktonic Marine Diatom Diversity and Correlation to Climate Change. PLoS ONE 2014, 9, e84857. [CrossRef] [PubMed]

67. Renaudie, J. Quantifying the Cenozoic marine diatom deposition history: Links to the C and Si cycles. Biogeosciences 2016, 13, 6003-6014. [CrossRef]

68. Baldauf, J.G.; Barron, J.A. Evolution of Biosiliceous Sedimentation Patterns—Eocene Through Quaternary: Paleoceanographic Response to Polar Cooling. In Geological History of the Polar Oceans: Arctic versus Antarctic; Bleil, U., Thiede, J., Eds.; Springer: Dordrecht, The Netherlands, 1990; pp. 575-607. [CrossRef]

69. Diester-Haass, L.; Meyers, P.A.; Vidal, L. The late Miocene onset of high productivity in the Benguela Current upwelling system as part of a global pattern. Mar. Geol. 2002, 180, 87-103. [CrossRef]

70. Norris, R.D.; Turner, S.K.; Hull, P.M.; Ridgwell, A. Marine Ecosystem Responses to Cenozoic Global Change. Science 2013, 341, 492-498. [CrossRef]

71. Santini, F.; Sorenson, L. First molecular timetree of billfishes (Istiophoriformes: Acanthomorpha) shows a Late Miocene radiation of marlins and allies. Ital. J. Zool. 2013, 80, 481-489. [CrossRef]

72. Schwarzhans, W.; Aguilera, O. Otoliths of the Myctophidae from the Neogene of tropical America. Palaeo-Ichthyologica 2013, 13, 83-150.

73. Pyenson, N.D.; Vermeij, G.J. The rise of ocean giants: Maximum body size in Cenozoic marine mammals as an indicator for productivity in the Pacific and Atlantic Oceans. Biol. Lett. 2016, 12, 20160186. [CrossRef]

74. Warheit, K.I. The seabird fossil record and the role of paleontology in understanding seabird community structure. In Biology of Marine Birds; Schreiber, E.A., Burger, J., Eds.; CRC Press: Boca Raton, FL, USA, 2001; pp. 17-55. [CrossRef]

75. Brachert, T.C.; Bornemann, A.; Reuter, M.; Galer, S.J.; Grimm, K.I.; Fassoulas, C. Upwelling history of the Mediterranean Sea revealed by stunted growth in the planktic foraminifera Orbulina universa (early Messinian, Crete, Greece). Int. J. Earth Sci. 2015, 104, 263-276. [CrossRef]

76. Sierro, F.J.; Flores, J.A.; Francés, G.; Vazquez, A.; Utrilla, R.; Zamarreño, I.; Erlenkeuser, H.; Barcena, M.A. Orbitally-controlled oscillations in planktic communities and cyclic changes in western Mediterranean hydrography during the Messinian. Palaeogeogr. Palaeoclimatol. Palaeoecol. 2003, 190, 289-316. [CrossRef]

77. Antonarakou, A.; Kontakiotis, G.; Zarkogiannis, S.; Mortyn, P.G.; Drinia, H.; Koskeridou, E.; Anastasakis, G. Planktonic foraminiferal abnormalities in coastal and open marine eastern Mediterranean environments: A natural stress monitoring approach in recent and early Holocene marine systems. J. Mar. Syst. 2018, 181, 63-78. [CrossRef]

78. Schmidt, D.N.; Lazarus, D.; Young, J.R.; Kucera, M. Biogeography and evolution of body size in marine plankton. Earth-Sci. Rev. 2006, 78, 239-266. [CrossRef]

79. Knappertsbusch, M. Morphologic Evolution of the Coccolithophorid Calcidiscus leptoporus from the Early Miocene to Recent. J. Paleontol. 2000, 74, 712-730. [CrossRef]

80. Young, J. Size variation of Neogene Reticulofenestra coccoliths from Indian Ocean DSDP Cores. J. Micropalaeontol. 1990, 9, 71-85. [CrossRef]

81. Broecker, W.S.; Peng, T.-H. The role of $\mathrm{CaCO}_{3}$ compensation in the glacial to interglacial atmospheric $\mathrm{CO}_{2}$ change. Glob. Biogeochem. Cycles 1987, 1, 15-29. [CrossRef]

82. Bramlette, M.N. Pelagic sediments. In Oceanography; Sears, M., Ed.; American Association for the Advancement of Science: Washington, DC, USA, 1961; pp. 345-366.

83. Berger, W.H. Biogenous Deep-Sea Sediments: Fractionation by Deep-Sea Circulation. GSA Bull. 1970, 81, 1385-1402. [CrossRef] 
84. Milliman, J.; Droxler, A. Neritic and pelagic carbonate sedimentation in the marine environment: Ignorance is not bliss. Geol. Rundsch. 1996, 85, 496-504. [CrossRef]

85. Berger, W.H.; Wefer, G. Expeditions into the Past: Paleoceanographic Studies in the South Atlantic. In The South Atlantic: Present and Past Circulation; Springer: Berlin/Heidelberg, Germany, 1996; pp. 363-410. [CrossRef]

86. Van Andel, T.H.; Thiede, J.; Sclater, J.G.; Hay, W.W. Depositional History of the South Atlantic Ocean during the Last 125 Million Years. J. Geol. 1977, 85, 651-698. [CrossRef]

87. Hsü, K.J.; Wright, R. History of calcite dissolution of the South Atlantic Ocean. In South Atlantic Paleoceanography; Hsü, K.J., Weissert, H.J., Eds.; Cambridge University Press: Cambridge, UK, 1985; pp. 149-187.

88. Hagelberg, T.K.; Shackleton, N.J.; Pisias, N.G.; Mayer, L.A.; Janecek, T.R.; Baldauf, J.G.; Bloomer, S.F.; Dadey, K.A.; Emeis, K.-C.; Farrell, J.; et al. Development of composite depth sections for sites 844 through 854. Proc. Ocean Drill. Program 1991, $138,79$. [CrossRef]

89. Kemp, A.E.S.; Baldauf, J.G.; Pearce, R.B. Origins and paleoceanographic significance of laminated diatom ooze from the eastern Equatorial Pacific Ocean. Proc. Ocean Drill. Program 1995, 138, 641. [CrossRef]

90. Kemp, A.E.S.; Baldauf, J.G. Vast Neogene laminated diatom mat deposits from the eastern equatorial Pacific Ocean. Nature 1993, 362, 141-144. [CrossRef]

91. Pellegrino, L.; Dela Pierre, F.; Natalicchio, M.; Carnevale, G. The Messinian diatomite deposition in the Mediterranean region and its relationships to the global silica cycle. Earth-Sci. Rev. 2018, 178, 154-176. [CrossRef]

92. Kemp, A.E.S.; Pearce, R.B.; Grigorov, I.; Rance, J.; Lange, C.B.; Quilty, P.; Salter, I. Production of giant marine diatoms and their export at oceanic frontal zones: Implications for Si and C flux from stratified oceans. Glob. Biogeochem. Cycles 2006, 20. [CrossRef]

93. Romero, O.E.; Thunell, R.C.; Astor, Y.; Varela, R. Seasonal and interannual dynamics in diatom production in the Cariaco Basin, Venezuela. Deep Sea Res. Part I Oceanogr. Res. Pap. 2009, 56, 571-581. [CrossRef]

94. Romero, O.E.; Armand, L.K. Marine diatoms as indicators of modern changes in oceanographic conditions. In The Diatoms: Applications for the Environmental and Earth Sciences, 2nd ed.; Smol, J.P., Stoermer, E.F., Eds.; Cambridge University Press: Cambridge, UK, 2010; pp. 373-400.

95. Bacon, M.P. Glacial to interglacial changes in carbonate and clay sedimentation in the Atlantic Ocean estimated from ${ }^{230} \mathrm{Th}$ measurements. Chem. Geol. 1984, 46, 97-111. [CrossRef]

96. Francois, R.; Frank, M.; Rutgers van der Loeff, M.M.; Bacon, M.P. ${ }^{230}$ Th normalization: An essential tool for interpreting sedimentary fluxes during the late Quaternary. Paleoceanography 2004, 19. [CrossRef]

97. Marcantonio, F.; Anderson, R.F.; Stute, M.; Kumar, N.; Schlosser, P.; Mix, A. Extraterrestrial ${ }^{3}$ He as a tracer of marine sediment transport and accumulation. Nature 1996, 383, 705-707. [CrossRef]

98. Kienast, S.S.; Kienast, M.; Mix, A.C.; Calvert, S.E.; François, R. Thorium-230 normalized particle flux and sediment focusing in the Panama Basin region during the last 30,000 years. Paleoceanography 2007, 22. [CrossRef]

99. Archer, D.E. Equatorial Pacific Calcite Preservation Cycles: Production or Dissolution? Paleoceanography 1991, 6, 561-571. [CrossRef]

100. Tréguer, P.; Nelson, D.M.; Van Bennekom, A.J.; DeMaster, D.J.; Leynaert, A.; Quéguiner, B. The Silica Balance in the World Ocean: A Reestimate. Science 1995, 268, 375-379. [CrossRef] [PubMed]

101. Pearce, R.B.; Kemp, A.E.S.; Baldauf, J.G.; King, S.C. High-resolution sedimentology and micropaleontology of laminated diatomaceous sediments from the eastern Equatorial Pacific Ocean. Proc. Ocean Drill. Program 1995, 138, 647. [CrossRef]

102. Wise, S.W. Chalk Formation: Early Diagenesis. In The Fate of Fossil Fuel $\mathrm{CO}_{2}$ in the Oceans; Andersen, N., Ed.; Springer: New York, NY, USA, 1977; p. 749.

103. Dittert, N.; Baumann, K.-H.; Bickert, T.; Henrich, R.; Huber, R.; Kinkel, H.; Meggers, H. Carbonate Dissolution in the Deep-Sea: Methods, Quantification and Paleoceanographic Application. In Use of Proxies in Paleoceanography: Examples from the South Atlantic; Fischer, G., Wefer, G., Eds.; Springer: Berlin/Heidelberg, Germany, 1999; pp. 255-284. [CrossRef]

104. Berger, W.H.; Bonneau, M.C.; Parker, F.L. Foraminifera on the deep-sea floor: Lysocline and dissolution rate. Oceanol. Acta 1982, 5, 249-258.

105. Peterson, L.C.; Prell, W.L. Carbonate dissolution in Recent sediments of the eastern equatorial Indian Ocean: Preservation patterns and carbonate loss above the lysocline. Mar. Geol. 1985, 64, 259-290. [CrossRef]

106. Le, J.; Shackleton, N.J. Carbonate Dissolution Fluctuations in the Western Equatorial Pacific During the Late Quaternary. Paleoceanography 1992, 7, 21-42. [CrossRef]

107. Conan, S.M.H.; Ivanova, E.M.; Brummer, G.J.A. Quantifying carbonate dissolution and calibration of foraminiferal dissolution indices in the Somali Basin. Mar. Geol. 2002, 182, 325-349. [CrossRef]

108. Gibbs, S.J.; Shackleton, N.J.; Young, J.R. Identification of dissolution patterns in nannofossil assemblages: A high-resolution comparison of synchronous records from Ceara Rise, ODP Leg 154. Paleoceanography 2004, 19. [CrossRef]

109. Zachos, J.C.; Kroon, D.; Blum, P.; Bowles, J.; Gaillot, P.; Hasegawa, T.; Hathorne, E.C.; Hodell, D.A.; Kelly, D.C.; Jung, J.-H.; et al. Proceedings of the Ocean Drilling Program; Initial Reports; Early Cenozoic Extreme Climates; the Walvis Ridge Transect; Covering Leg 208 of the Cruises of the Drilling Vessel JOIDES Resolution; Rio de Janeiro, Brazil, to Rio de Janeiro, Brazil; sites 1262-1267, 6 March-6 May 2003; Ocean Drilling Program: College Station, TX, USA, 2004. [CrossRef]

110. Berger, W.H.; Leckie, R.M.; Janecek, T.R.; Stax, R.; Takayama, T. Neogene carbonate sedimentation on Ontong Java Plateau; highlights and open questions. Proc. Ocean Drill. Program 1993, 130, 711-744. [CrossRef] 
111. Flores, J.A.; Sierro, F.J.; Raffi, I. Evolution of the calcareous nannofossil assemblage as a response to the paleoceanographic changes in the eastern Equatorial Pacific Ocean from 4 to 2 Ma (Leg 138, sites 849 and 852). Proc. Ocean Drill. Program 1995, 138, 163. [CrossRef]

112. Shackleton, N.J.; Crowhurst, S.; Hagelberg, T.; Pisias, N.G.; Schneider, D.A. A new late Neogene time scale; application to Leg 138 sites. Proc. Ocean Drill. Program 1995, 138, 73. [CrossRef]

113. Backman, J.; Raffi, I. Calibration of Miocene nannofossil events to orbitally tuned cyclostratigraphies from Ceara Rise. Proc. Ocean Drill. Program 1997, 154, 83. [CrossRef]

114. Berggren, W.A.; Kent, D.V.; Swisher, C.C., III; Aubry, M.-P. A Revised Cenozoic Geochronology and Chronostratigraphy. In Geochronology, Time Scales and Global Stratigraphic Correlation; Berggren, W.A., Kent, D.V., Aubry, M.-P., Hardenbol, J., Eds.; SEPM Society for Sedimentary Geology: Tulsa, OK, USA, 1995; Volume 54.

115. Nathan, S.A.; Leckie, R.M. Early history of the Western Pacific Warm Pool during the middle to late Miocene ( 13.2-5.8 Ma): Role of sea-level change and implications for equatorial circulation. Palaeogeogr. Palaeoclimatol. Palaeoecol. 2009, 274, 140-159. [CrossRef]

116. Fornaciari, E. Calcareous nannofossil biostratigraphy of the California margin. Proc. Ocean Drill. Program 2000, 167, 3. [CrossRef]

117. Cande, S.C.; Kent, D.V. Revised calibration of the geomagnetic polarity timescale for the Late Cretaceous and Cenozoic. J. Geophys. Res. Solid Earth 1995, 100, 6093-6095. [CrossRef]

118. Vincent, E.; Toumarkine, M. Data report; Miocene planktonic foraminifers from the eastern Equatorial Pacific. Proc. Ocean Drill. Program 1995, 138, 895. [CrossRef]

119. Shackleton, N.J.; Hall, M.A. Stable isotope records in bulk sediments (Leg 138). Proc. Ocean Drill. Program 1995, $138,797$. [CrossRef]

120. Raffi, I.; Flores, J.-A. Pleistocene through Miocene calcareous nannofossils from eastern Equatorial Pacific Ocean (Leg 138). Proc. Ocean Drill. Program 1995, 138, 233. [CrossRef]

121. Mix, A.C.; Tiedemann, R.; Blum, P.; Abrantes, F.F.; Benway, H.; Cacho-Lascorz, I.; Chen, M.-T.; Delaney, M.L.; Flores, J.-A.; Giosan, L.; et al. Proceedings of the Ocean Drilling Program, Initial Reports, Southeast Pacific Paleoceanographic Transects; Covering Leg 202 of the Cruises of the Drilling Vessel JOIDES Resolution; Valparaiso, Chile, to Balboa, Panama; Sites 1232-1242, 29 March-30 May 2002; Ocean Drilling Program: College Station, TX, USA, 2003. [CrossRef]

122. Lyle, M.; Koizumi, I.; Richter, C.; Behl, R.J.; Boden, P.; Caulet, J.-P.; Delaney, M.L.; deMenocal, P.; Desmet, M.; Fornaciari, E.; et al. Proceedings of the Ocean Drilling Program; Initial Reports, California Margin; Covering Leg 167 of the Cruises of the Drilling Vessel JOIDES Resolution, Acapulco, Mexico, to San Francisco, California, Sites 1010-1022, 20 April-16 June 1996; Ocean Drilling Program: College Station, TX, USA, 1997; p. 1378. [CrossRef]

123. Lyle, M. Neogene carbonate burial in the Pacific Ocean. Paleoceanography 2003, 18. [CrossRef]

124. Berger, W.H. Produktivität des Ozeans aus geologischer Sicht: Denkmodelle und Beispiele [Ocean Productivity from the Viewpoint of Geology: Concepts and Examples]. Zeitschrift der Deutschen Geologischen Gesellschaft 1991, 149-178. [CrossRef]

125. Preiss-Daimler, I.V.; Henrich, R.; Bickert, T. The final Miocene carbonate crash in the Atlantic: Assessing carbonate accumulation, preservation and production. Mar. Geol. 2013, 343, 39-46. [CrossRef]

126. Shackleton, N.J.; Crowhurst, S. Sediment fluxes based on an orbitally tuned time scale 5 Ma to 14 Ma, Site 926. Proc. Ocean Drill. Program 1997, 154, 69. [CrossRef]

127. Kameo, K.; Sato, T. Biogeography of Neogene calcareous nannofossils in the Caribbean and the eastern equatorial Pacific-floral response to the emergence of the Isthmus of Panama. Mar. Micropaleontol. 2000, 39, 201-218. [CrossRef]

128. Kameo, K.; Bralower, T.J. Neogene calcareous nannofossil biostratigraphy of sites 998, 999, and 1000, Caribbean Sea. Proc. Ocean Drill. Program 2000, 165, 3. [CrossRef]

129. Rio, D.; Fornaciari, E.; Raffi, I. Late Oligocene through early Pleistocene calcareous nannofossils from western equatorial Indian Ocean (Leg 115). Proc. Ocean Drill. Program 1990, 115, 175. [CrossRef]

130. Ravelo, A.C.; Dekens, P.S.; McCarthy, M. Evidence for El Niño-like conditions during the Pliocene. GSA Today 2006, $16,4-11$. [CrossRef]

131. Rippert, N.; Nürnberg, D.; Raddatz, J.; Maier, E.; Hathorne, E.; Bijma, J.; Tiedemann, R. Constraining foraminiferal calcification depths in the western Pacific warm pool. Mar. Micropaleontol. 2016, 128, 14-27. [CrossRef]

132. Dugdale, R.C.; Wischmeyer, A.G.; Wilkerson, F.P.; Barber, R.T.; Chai, F.; Jiang, M.S.; Peng, T.H. Meridional asymmetry of source nutrients to the equatorial Pacific upwelling ecosystem and its potential impact on ocean-atmosphere $\mathrm{CO}_{2}$ flux; a data and modeling approach. Deep Sea Res. Part II Top. Stud. Oceanogr. 2002, 49, 2513-2531. [CrossRef]

133. Goodman, P.J.; Hazeleger, W.; Vries, P.D.; Cane, M. Pathways into the Pacific Equatorial Undercurrent: A Trajectory Analysis. J. Phys. Oceanogr. 2005, 35, 2134-2151. [CrossRef]

134. McPhaden, M.J.; Zebiak, S.E.; Glantz, M.H. ENSO as an Integrating Concept in Earth Science. Science 2006, 314, 1740-1745. [CrossRef] [PubMed]

135. Keller, K.M.; Joos, F.; Lehner, F.; Raible, C.C. Detecting changes in marine responses to ENSO from 850 to 2100 C.E.: Insights from the ocean carbon cycle. Geophys. Res. Lett. 2015, 42, 518-525. [CrossRef]

136. Zhang, Y.G.; Pagani, M.; Henderiks, J.; Ren, H. A long history of equatorial deep-water upwelling in the Pacific Ocean. Earth Planet. Sci. Lett. 2017, 467, 1-9. [CrossRef] 
137. Vincent, E. Neogene carbonate stratigraphy of Hess Rise (central North Pacific) and paleoceanographic implications. Proc. Ocean Drill. Program 1981, 62, 571. [CrossRef]

138. Ren, J.; Gersonde, R.; Esper, O.; Sancetta, C. Diatom distributions in northern North Pacific surface sediments and their relationship to modern environmental variables. Palaeogeogr. Palaeoclimatol. Palaeoecol. 2014, 402, 81-103. [CrossRef]

139. Kennett, J.P.; Keller, G.; Srinivasan, M.S. Miocene planktonic foraminiferal biogeography and paleoceanographic development of the Indo-Pacific region. In The Miocene Ocean: Paleoceanography and Biogeography; Kennett, J.P., Ed.; Geological Society of America: Boulder, CO, USA, 1985; Volume 163, pp. 197-236.

140. Li, Q.; Li, B.; Zhong, G.; McGowran, B.; Zhou, Z.; Wang, J.; Wang, P. Late Miocene development of the western Pacific warm pool: Planktonic foraminifer and oxygen isotopic evidence. Palaeogeogr. Palaeoclimatol. Palaeoecol. 2006, 237, 465-482. [CrossRef]

141. Chavez, F.P.; Pennington, J.T.; Castro, C.G.; Ryan, J.P.; Michisaki, R.P.; Schlining, B.; Walz, P.; Buck, K.R.; McFadyen, A.; Collins, C.A. Biological and chemical consequences of the 1997-1998 El Niño in central California waters. Prog. Oceanogr. 2002, 54, 205-232. [CrossRef]

142. Takesue, R.K.; van Geen, A.; Carriquiry, J.D.; Ortiz, E.; Godínez-Orta, L.; Granados, I.; Saldívar, M.; Ortlieb, L.; Escribano, R.; Guzman, N.; et al. Influence of coastal upwelling and El Niño-Southern Oscillation on nearshore water along Baja California and Chile: Shore-based monitoring during 1997-2000. J. Geophys. Res. Oceans 2004, 109. [CrossRef]

143. de Villiers, S. Foraminiferal shell-weight evidence for sedimentary calcite dissolution above the lysocline. Deep Sea Res. Part I Oceanogr. Res. Pap. 2005, 52, 671-680. [CrossRef]

144. deMenocal, P.B.; Oppo, D.W.; Fairbanks, R.G.; Prell, W.L. Pleistocene $\delta^{13}$ C Variability of North Atlantic Intermediate Water. Paleoceanography 1992, 7, 229-250. [CrossRef]

145. Sverdrup, H.U.; Johnson, M.W.; Fleming, R.H. The Oceans: Their Physics, Chemistry, and General Biology; Prentice-Hall, Inc.: New York, NY, USA, 1942.

146. Haug, G.H.; Tiedemann, R.; Zahn, R.; Ravelo, A.C. Role of Panama uplift on oceanic freshwater balance. Geology 2001, 29, 207-210. [CrossRef]

147. Haddad, G.A.; Droxler, A.W. Metastable $\mathrm{CaCO}_{3}$ dissolution at intermediate water depths of the Caribbean and western North Atlantic: Implications for intermediate water circulation during the past 200,000 years. Paleoceanography 1996, 11, 701-716. [CrossRef]

148. Dickens, G.R.; O'Neil, J.R.; Rea, D.K.; Owen, R.M. Dissociation of oceanic methane hydrate as a cause of the carbon isotope excursion at the end of the Paleocene. Paleoceanography 1995, 10, 965-971. [CrossRef]

149. Dickens, G.R. Methane oxidation during the late Palaeocene thermal maximum. Bulletin de la Société Géologique de France 2000, $171,37-49$.

150. Chepstow-Lusty, A.; Backman, J.; Shackleton, N.J. Palaeoclimatic control of Upper Pliocene Discoaster assemblages in the North Atlantic. J. Micropalaeontol. 1991, 9, 133-143. [CrossRef]

151. Nisancioglu, K.H.; Raymo, M.E.; Stone, P.H. Reorganization of Miocene deep water circulation in response to the shoaling of the Central American Seaway. Paleoceanography 2003, 18. [CrossRef]

152. Heinze, C.; Crowley, T.J. Sedimentary response to ocean gateway circulation changes. Paleoceanography 1997, 12, 742-754. [CrossRef]

153. Farrell, J.W.; Prell, W.L. Pacific $\mathrm{CaCO}_{3}$ Preservation and $\delta^{18} \mathrm{O}$ Since 4 Ma: Paleoceanic and Paleoclimatic Implications. Paleoceanography 1991, 6, 485-498. [CrossRef]

154. Siesser, W.G. Late Miocene Origin of the Benguela Upswelling System off Northern Namibia. Science 1980, $208,283-285$. [CrossRef]

155. Boltovskoy, E.; Totah, V. Preservation index and preservation potential of some foraminiferal species. J. Foraminifer. Res. 1992, 22, 267-273. [CrossRef]

156. Nguyen, T.M.P.; Petrizzo, M.R.; Speijer, R.P. Experimental dissolution of a fossil foraminiferal assemblage (Paleocene-Eocene Thermal Maximum, Dababiya, Egypt): Implications for paleoenvironmental reconstructions. Mar. Micropaleontol. 2009, 73, 241-258. [CrossRef]

157. Roters, B.; Henrich, R. The middle to late Miocene climatic development of Southwest Africa derived from the sedimentological record of ODP Site 1085A. Int. J. Earth Sci. 2010, 99, 459-471. [CrossRef]

158. Oppo, D.W.; Fairbanks, R.G. Variability in the deep and intermediate water circulation of the Atlantic Ocean during the past 25,000 years: Northern Hemisphere modulation of the Southern Ocean. Earth Planet. Sci. Lett. 1987, 86, 1-15. [CrossRef]

159. Butzin, M.; Lohmann, G.; Bickert, T. Miocene ocean circulation inferred from marine carbon cycle modeling combined with benthic isotope records. Paleoceanography 2011, 26. [CrossRef]

160. Gupta, A.K.; Singh, R.K.; Joseph, S.; Thomas, E. Indian Ocean high-productivity event (10-8 Ma): Linked to global cooling or to the initiation of the Indian monsoons? Geology 2004, 32, 753-756. [CrossRef]

161. Woodruff, F.; Savin, S.M. Miocene deepwater oceanography. Paleoceanography 1989, 4, 87-140. [CrossRef]

162. Smart, C.W.; Thomas, E.; Ramsay, A.T.S. Middle-late Miocene benthic foraminifera in a western equatorial Indian Ocean depth transect: Paleoceanographic implications. Palaeogeogr. Palaeoclimatol. Palaeoecol. 2007, 247, 402-420. [CrossRef]

163. Dickens, G.R.; Owen, R.M. The Latest Miocene-Early Pliocene biogenic bloom: A revised Indian Ocean perspective. Mar. Geol. 1999, 161, 75-91. [CrossRef] 
164. Singh, R.K.; Gupta, A.K. Systematic decline in benthic foraminiferal species diversity linked to productivity increases over the last $26 \mathrm{Ma}$ in the Indian Ocean. J. Foraminifer. Res. 2005, 35, 219-227. [CrossRef]

165. Vincent, E.; Toumarkine, M. Neogene planktonic foraminifers from the western tropical Indian Ocean, Leg 115. Proc. Ocean Drill. Program 1990, 115, 795. [CrossRef]

166. Zhang, Y.G.; Pagani, M.; Liu, Z.; Bohaty, S.M.; DeConto, R. A 40-million-year history of atmospheric $\mathrm{CO}_{2}$. Philos. Trans. R. Soc. A Math. Phys. Eng. Sci. 2013, 371, 20130096. [CrossRef] [PubMed]

167. Pearson, P.N.; Palmer, M.R. Atmospheric carbon dioxide concentrations over the past 60 million years. Nature 2000, 406, 695-699. [CrossRef] [PubMed]

168. Mutti, M. Bulk $\delta^{18} \mathrm{O}$ and $\delta^{13} \mathrm{C}$ records from Site 999, Colombian Basin, and Site 1000, Nicaraguan Rise (latest Oligocene to middle Miocene); diagenesis, link to sediment parameters, and paleoceanography. Proc. Ocean Drill. Program 2000, 165, 275. [CrossRef]

169. Shackleton, N.J.; Hall, M.A. The late Miocene stable isotope record, Site 926. Proc. Ocean Drill. Program 1997, 154, 367. [CrossRef] 